\title{
Weights of evidence modeling for landslide susceptibility mapping of Kabi-Gebro locality, Gundomeskel area, Central Ethiopia
}

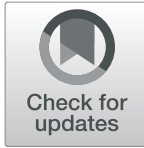

Nega Getachew ${ }^{1,2}$ and Matebie Meten ${ }^{1,3^{*}}$ (D)

\begin{abstract}
Kabi-Gebro locality of Gundomeskel area is located within the Abay Basin at Dera District of North Shewa Zone in the Central highland of Ethiopia and it is about $320 \mathrm{Km}$ from Addis Ababa. This is characterized by undulating topography, intense rainfall, active erosion and highly cultivated area. Geologically, it comprises weathered sedimentary and volcanic rocks. Active landslides damaged the gravel road, houses and agricultural land. The main objective of this research is to prepare the landslide susceptibility map using GIS-based Weights of Evidence model. Based on detailed field assessment and Google Earth image interpretation, 514 landslides were identified and classified randomly into training landslides (80\%) and validation landslides (20\%). The most common types of landslides in the study area include earth slide (rotational and translational slide), debris slide, debris flow, rock fall, topple, rock slide, creep and complex. Nine landslide causative factors such as lithology, slope, aspect, curvature, land use/land cover, distance to stream, distance to lineament, distance to spring and rainfall were used to prepare a landslide susceptibility map of the study area by adding the weights of contrast values of these causative factors using a rater calculator of the spatial analyst tool in ArcGIS. The final landslide susceptibility map was reclassified as very low, low, moderate, high and very high susceptibility classes. This susceptibility map was validated using landslide density index and area under the curve (AUC). The result from this model validation showed a success rate and a validation rate accuracy of $82.4 \%$ and $83.4 \%$ respectively. Finally, implementing afforestation strategies on bare land, constructing surface drainage channels \& ditches, providing engineering reinforcements such as gabion walls, retaining walls, anchors and bolts whenever necessary and prohibiting hazardous zones can be recommended in order to lessen the impact of landslides in this area.
\end{abstract}

Keywords: Landslide susceptibility, GIS, Weights of evidence, Kabi-Gebro, Gundomeskel, Ethiopia

\section{Introduction}

Most natural hazards are frequently related to mountainous regions. From the natural hazards, Landslide is one of the greatest disasters that cause different levels of injuries, life loss as well as damages to built-up and natural environment (Kanungo et al. 2006; Pan et al. 2008; Ghosh et al. 2012, Girma et al. 2015). Landslide is the

\footnotetext{
* Correspondence: matebe21@gmail.com

'Department of Geology, College of Applied Sciences, Addis Ababa Science and Technology University, P.O. Box: 16417, Addis Ababa, Ethiopia ${ }^{3}$ Mineral Exploration, Extraction and Processing Center of Excellence, Addis Ababa Science and Technology University, Addis Ababa, Ethiopia Full list of author information is available at the end of the article
}

downslope movement of rock, debris, or earth material (Cruden 1991). Landslides were caused by internal and external factors (Crozier 1986; Siddle et al. 1991). The internal factors represent the inherent attributes of the ground which make the slopes susceptible to landslides. These include geological materials, geological structures and geomorphology that allow the external factors to trigger a landslide. The most common external factors that initiate or accelerate the movement include seismicity, climate and anthropogenic factors. Landslides occur through a complex interplay of these conditioning (internal) factors (lithology, strength, geologic structures, 
geomorphic, geometric, hydrogeologic and stress conditions) and triggering (external) factors (rainfall, seismicity and anthropogenic activities). Triggering factors cause slope instability if sets of conditions are met and act on soils and rock masses to modify the characteristics, properties and conditions of slope equilibrium (de Vallejo and Ferrer 2011).

The landslide related causalities and economic losses will be greater as compared with other natural hazards in the world (Yilmaz 2009). Proper investigation on landslide inventory and causative factors will help to prepare the landslide susceptibility map which may reduce landslide related impacts on property and life (Brabb 1993).

Landslide hazard is a common problem that causes a considerable damage in the highlands of Ethiopia. In many parts of the Ethiopian highlands, landslide hazards are the most destructive natural phenomena which cause property damages including failures of engineering structures, human suffering, environmental degradation and loss of fertile agricultural lands (Ayalew 1999; Ayalew 2000; Ayalew and Yamagishi 2004; Ayenew and Barbieri 2005; Woldearegay 2013). From 1960 to 2010, landslide caused loss of 388 lives, injured 24 people and damaged cultivated land, environment, infrastructure and houses (Ayalew 1999; Temesgen et al. 1999; Woldearegay 2008; Ibrahim 2011; Meten et al. 2015a). The landslide incidence increase with serious damages on lives and properties in the highland of Ethiopia in recent decades (Meten et al. 2015b). Rainfall induced landslides have killed 62 people, injured 30 people, displaced 5091 people from their residence and damage house and cultivated land in 2018 (Wubalem and Meten 2020). The major intrinsic causes for landslide occurrence in the highland of Ethiopia include geological, geomorphological and hydrogeological factors that are triggered by heavy rainfall (Woldearegay 2013; Ermias et al. 2017). Many active landslides exist within the highlands of Ethiopia that are reactivated by heavy rainfall at the end of August (Ayalew 1999; Woldearegay 2013).

The Kabi-Gebro locality is also one of the potential sites where frequent landslides occur in the central highlands of Ethiopia. Currently, landslide incidences are posing serious challenges in road construction, agricultural practices and the livelihood of local people who settled at the foot and scarp of steep slopes. The active landslides damaged the constructed gravel road, house and agricultural land. Landslides occurred when a gravel road was under construction. Hence, the road alignment was changed without proper study. The frequent damage of this road has considerably increased the maintenance costs and delay the construction period. The large landslide that occurred on a gentle slope caused the displacement of local people from their home and damaged their crops. Therefore, identifying landslide location, causative factors and preparation of a susceptibility map is very important for the safe construction of infrastructures and the stability of the farmland in steep slopes. Moreover, it is also helps to recommend preventive and mitigation measures that contribute to a sustainable infrastructure development for a safer human livelihood.

The aim of this study is to locate landslides and to prepare the landslide susceptibility map of the KabiGebro locality of Dera District in Central Ethiopia. Landslide susceptibility is the likelihood that landslide occurs in a certain area (Mathew et al. 2007). The reliability of the landslide susceptibility map can be determined by the causative factors used, distribution of factors in the area and the model used in landslide susceptibility mapping (Kumar and Anbalagan 2019). The landslide susceptibility map can be developed from the spatial association between landslides and influencing factors. This is very important in landslide investigation, risk management and landslide hazard zonation. A landslide susceptibility map can be prepared through four main steps: (1) the landslide inventory map will be prepared; (2) landslide controlling factor maps will be prepared; (3) the most appropriate method will be applied to evaluate the weights of each factor and finally (4) the landslide susceptibility map will be prepared using a GIS procedure (van Westen et al. 1997). Several approaches have been developed for landslide susceptibility mapping. These approaches can be grouped into qualitative and quantitative methods (Aleotti and Chowdhury 1999; Kanungo et al. 2009; Pardeshi et al. 2013). Qualitative methods are based on expert opinions or entirely on the judgment of the person that conduct the landslide susceptibility or hazard assessment (Anbalagan 1992; Aleotti and Chowdhury 1999; Ayalew and Yamagishi 2005). This method includes field geomorphological analysis and overlaying of index maps with or without a weighting approach (Leroi 1996). Quantitative methods are data driven and based on numerical expressions between landslide controlling factors and landslide events. Quantitative methods can be either statistical or deterministic ones (Aleotti and Chowdhury 1999). Statistical approaches are based on numerical values driven from the relation between landslide distribution and landslide controlling factors (Guzzetti et al. 1999; Wubalem 2021). Statistical approaches can be categorized into bivariate and multivariate (Carrara et al. 2003; Suzen and Doyuran 2004a; Yalcin 2008; Pardeshi et al. 2013). Bivariate statistical methods correlate each data layer of the causative factors with existing landslide events and weighted values based on landslide density (Pardeshi et al. 2013). Susceptibility maps were the result of all 
causative factors that may be assumed as the main limitation in bivariate statistical methods which calls for the application of multivariate statistical methods (Pardeshi et al. 2013). In a multivariate method, all relevant factors were evaluated and the relative contribution of each factor is weighted (Kanungo et al. 2009). Deterministic method is another numerical approach that can be applied in small to medium-sized areas. For this, detailed slope geometry, stratigraphy and geotechnical result are required (Janevski and Milanovski 2018). In this study, a bivariate statistical model known as weights of evidence model was used to prepare the landslide susceptibility map of the area. Several scholars applied weights of evidence model for landslide susceptibility mapping in different parts of the world with a high performance accuracy (Kumar et al. 2008; Ghosh et al. 2009; Blahut et al. 2010; Piacentini et al. 2012; Schicker and Moon 2012; Chen 2014; Sumatra et al. 2015; Bousta and Ait 2018; Mersha and Meten 2020). Nowadays, weights of evidence model is the most commonly applied method for landslide susceptibility mapping as the model is simple, easy to use and less time consuming (Van Westen and Terlien 1996; Suzen and Doyuran 2004; Neuhäuser et al. 2012). In this study, weights of evidence model was applied to prepare landslide susceptibility map and the results obtained from this research will help decision makers, civil engineers and geoscientists to take appropriate mitigation measures in order to prevent the severe impacts of landslides in this area.

\section{Study area}

Kabi-Gebro locality of Gundomeskel area is located at Dera District of North Shewa Zone near Gundomeskel town, Oromia Region in Central Ethiopia which is about $320 \mathrm{Km}$ from Addis Ababa (Fig. 1). The area is bounded between $38^{\circ} 33^{\prime} 35^{\prime \prime} \mathrm{E}$ and $38^{\circ} 42^{\prime} 9^{\prime \prime} \mathrm{E}$ longitudes and $10^{\circ} 21^{\prime} 48^{\prime \prime} \mathrm{N}$ and $10^{\circ} 14 ' 20^{\prime \prime} \mathrm{N}$ latitudes. This area is part of the Abay (Blue Nile) basin which is surrounded by many tributary rivers. The main rivers include Weleka and Shenkora Rivers. It is characterized by different geological processes in the past and active erosional activities up to the present time. As a result, undulating topographic features that contain valleys, very steep to gentle slopes and flat areas are manifested as shown in Fig. 2. The maximum elevation in the study area is $2524 \mathrm{~m}$ at the top of the plateau while the minimum elevation is $1296 \mathrm{~m}$ at the river course. The drainage network of the study area shows dendritic and parallel drainage patterns (Fig. 1) which were formed following the basalt and limestone cliffs respectively. Based on elevation difference, the climate of the study area is categorized under cool and humid in higher elevation and warm and semi-arid in lower elevation areas. The heaviest monthly rainfall records in July and August are $306.3 \mathrm{~mm}$ and $332.5 \mathrm{~mm}$ respectively. The complex geomorphology of the study area was carved out of the Mesozoic sedimentary and Cenozoic volcanic rocks. From bottom to top, Limestone, upper sandstone and moderately to highly weathered basalts constitute the stratigraphy of this area with different geological structures such as lineaments, faults, joints and sedimentary structures.

\section{Methods}

In this study, different activities were carried out both in-office and in the field starting from data collection, database generation, model application and validation.

\section{Data collection and source}

For this study, a landslide inventory map and landslide controlling factor maps were prepared from different sources. Review of relevant literatures such as journals, books and different reports has been undertaken. The important data like DEM data, landslide inventory of the study area, rainfall data from National Meteorology Agency of Ethiopia, regional geological map at a scale of 1:250,000 and reports from Geological Survey of Ethiopia and topographic maps at a scale of 1: 50,000 from Ethiopian Geospatial Information Agency were collected. Primarily, potential sites with serious past landslide problems were identified from Google Earth image interpretation in order to prepare the landslide distribution map for landslide susceptibility assessment. In addition, a series of field surveys have been conducted to study the type, activity, extent, damage and cause of landslides. The geological units, geological structures, land use/land cover and spring location were mapped. Moreover, a detail geological characterization has been done based on the physical properties of rocks and soils.

\section{GIS database}

In this study, a database for all causative factors (slope, aspect, curvature, lithology, land use, rainfall, distance to stream, distance to lineament and distance to spring) and landslide inventory map was prepared in GIS environment of ArcMap 10.4. The data layers were prepared in a raster format with the same projection system (Adindan UTM Zone $37 \mathrm{~N}$ ) and pixel size (30x30m) for data analysis.

\section{Landslide inventory map}

This study is based on the assumption that future landslides will occur under similar conditions as past landslides (Lee and Talib 2005). This means that the conditions of the past landslide occurrence (e.g. location, factors and slope material) is a key for the future. To prepare a landslide susceptibility map, landslide locations were properly identified and mapped. Landslide inventory map in the study area was prepared from Google Earth image interpretation and field investigation for accessible landslide locations. The landslide 


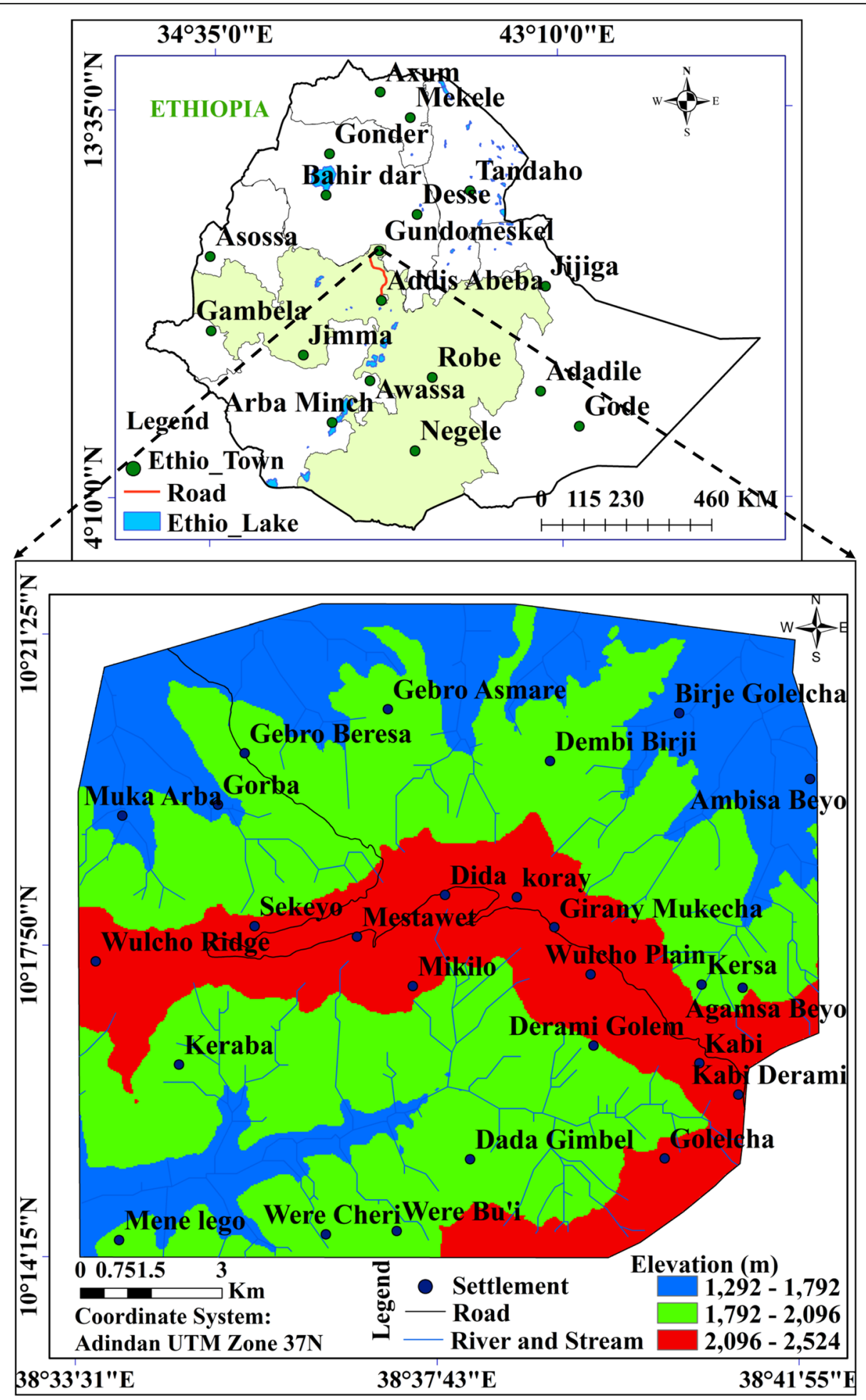

Fig. 1 Location Map of the study area

inventory data was prepared in polygon or vector format. A total of 514 landslides were identified which were randomly divided into training (80\%) and validation (20\%) landslides (Fig. 3). Low percentage of validation landslide was chosen in order to keep statistical strength in the model (Neuhäuser et al. 2012). The reduction of the training landslides leads to a decrease in likelihood values and lowering of the confidence of the weights. 


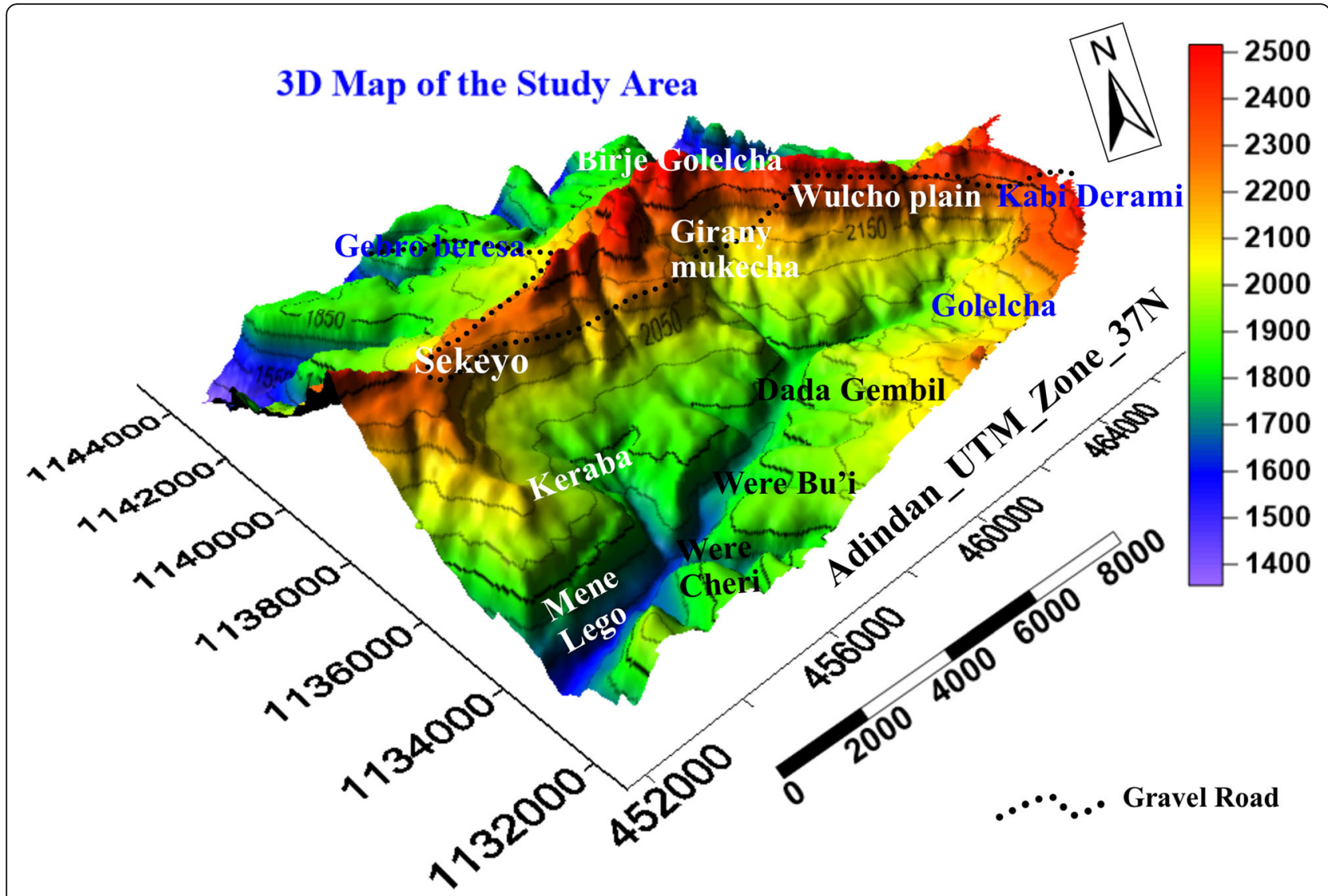

Fig. 2 Physiography of the study area

Finally, the landslide polygons were changed into a raster format in a GIS system with the same coordinate system and pixels size.

\section{Landslide causative factors}

A landslide susceptibility map depends on the complex association of landslide event and their causative factors. The causative factors which were taken into account for the assessment of a landslide susceptibility map have been selected based on literature review and detail field observations. In the case of landslide susceptibility mapping, there is no any standard rule to select which factor to be used or not, rather than deciding on the nature of area and data availability (Ayalew and Yamagishi 2005). On this basis, nine causative factors were selected as the main influencing factors for landslide occurrence which were prepared from different sources. Topographic parameters such as slope, aspect and curvature were extracted from DEM Data of $30 \times 30 \mathrm{~m}$ resolution. The distance to streams, distance to spring and distance to lineament were extracted from river map, spring location map and geologic structure map of the area respectively using GIS buffering. Lithological map was prepared through a detailed field mapping and Land use/land cover/ map was extracted from Google Earth image interpretation which is supported by field survey.

Rainfall map was prepared using GIS interpolation of rainfall stations from National Meteorology Agency of Ethiopia. All these factor maps were stored in a raster format with the same coordinate system (Adindan UTM Zone $37 \mathrm{~N}$ ) and pixels size (30x30m resolution). Then, the rasterized training landslide map and all factor maps were used in landslide susceptibility modeling. The weight was calculated for each factor class based on the correlation of landslides with each factor class using the weights of evidence model. Finally, the result was verified using a validation landslide data set (Fig. 4).

\section{Weights of evidence (WoE) model}

In this study, a bivariate statistical approach known as weights of evidence (WoE) model was used for landslide susceptibility mapping. WoE model is a data driven model which is based on Bayesian method and uses prior and conditional probability. Initially it was developed for mineral potential evaluation (Bonham-Carter et al. 1988, 1989; Agterberg et al. 1993) and later used for landslide susceptibility assessment (Van Westen et al. 2003, Lee et al. 2004; Lee and Talib 2005; Lee and Sambath 


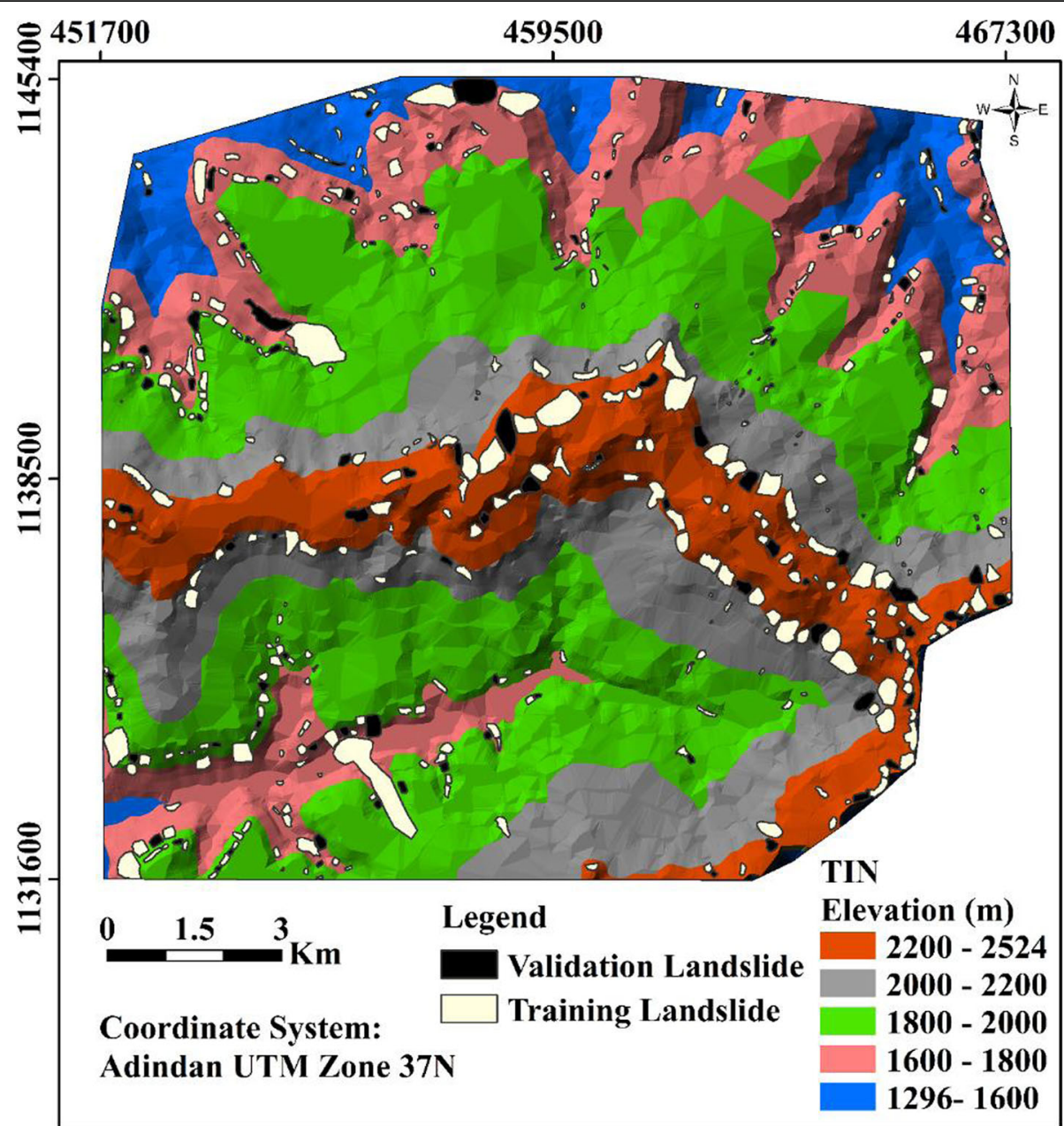

Fig. 3 Landslide inventory map of the study area

2006; Pradhan et al. 2010). In this method, the prior probability is determined based on the past landslide without additional information. The prior probability was calculated as number of pixels with landslides is divided by total number of pixels in the map (Bonham-Carter 1994).

$$
\text { Pprior }=\frac{\text { Area }(\text { slide })}{\text { Area }(\text { total })}
$$

As additional information about each causative factor is found, the prior probability will be modified to a conditional probability. According to Bonham-Carter (1994), all factors should be conditionally independent and the conditional probability can be expressed as follows:

$$
\mathrm{P}\{\mathrm{S} \mid \mathrm{B}\}=\frac{\mathrm{Npix}\{\mathrm{S} \cap \mathrm{B}\}}{\operatorname{Npix}\{\mathrm{B}\}}
$$

Where, Npix is number of pixel, $\mathrm{S}$ and $\mathrm{B}$ represent landslide and the factor respectively. By integrating landslides with landslide causative factors, the statistical association between classes of a factor map and landslides will be determined (Neuhäuser et al. 2012). The weight values can be calculated based on the contribution of causative factors to landslide occurrence. The positive and negative weights (Wi + and $\mathrm{Wi}-$ ) are calculated to know the spatial correlation in the presence or absence of the factor using the formula described by Bonham-Carter (1994) and Bonham-Carter et al. (1989):

$$
\begin{aligned}
& W+=\ln \left(\frac{\frac{N p i x 1}{N p i x 1+N p i x 2}}{\frac{N p i x 3}{N p i x 3+N p i x 4}}\right) \\
& W-=\ln \left(\frac{\frac{N p i x 2}{N p i x 1+N p i x 2}}{\frac{N p i x 4}{N p i x 3+N p i x 4}}\right)
\end{aligned}
$$

A positive weight $\left(\mathrm{Wi}^{+}\right)$shows that the causative factor is present at the landslide locations and the magnitude 
of this weight is an indication of the positive correlation between them. A negative weight $\left(\mathrm{Wi}^{-}\right)$shows the absence of the causative factor and the magnitude of this weight is an indication of the level of negative correlation.

The number of pixels in each class can be calculated as follows:

$1 \quad$ Npix $1=$ Nslclass

$2 \quad$ Npix $2=$ Nslide - Nslclass

3 Npix $3=$ Nclass - Nslclass

$4 \quad$ Npix4 = Nmap - Nslide - Nclass + nslclass

The above variables represent Nslide $=$ Number of pixels with landslides in the map, Nclass $=$ Number of pixels in the class, Nslclass $=$ Number of pixels with landslides in the class and Nmap=Total number of pixels in the map.

A weight of contrast is the difference between positive and negative weights. The magnitude of these contrast values reflects the overall spatial association between each causative factor class and the landslides. The positive contrast value indicates positive spatial associations while the negative ones for a negative spatial association.

$$
\begin{aligned}
& C=W^{+}-W^{-} \\
& \text {Wmap }=\sum C
\end{aligned}
$$

Finally, the landslide susceptibility index (LSI) is produced by combining the weighted map (Wmap) of each factor through summation process using Eq. 7 below. The final landslide susceptibility map was verified based on landslide validation.

$$
L S I=\sum W m a p
$$

\section{Landslide inventory}

It is becoming universal that landslide susceptibility mapping starts with landslide inventory mapping (Ayalew and Yamagishi 2004). Landslide inventory map is the simplest form of landslide distribution map (Hansen 1984). Landslide inventory maps can be prepared by different techniques depending on their purpose, the extent of the study area, the scales of base maps and aerial photographs and the resources available to carry out the work (Guzzetti 2000). It is the distribution of the past landslide which indicates landslide event in terms of space (location) and time. Identifying landslides from field studies only are expensive and time-consuming. In this study, landslide inventory map was prepared by interpreting Google Earth images and detail field assessment. A series of field surveys have been conducted to study the type, activity and extent of landslides. Landslide locations in the study area were verified during the fieldwork. In this study, $15.1 \mathrm{Km}^{2}$ (16,774 pixels) of landslide area was identified out of $199.5 \mathrm{Km}^{2}(221,755$ pixels) total area. From a total area of $15.1 \mathrm{Km}^{2}(16,774$ pixels), $12.08 \mathrm{Km}^{2}$ (13,405 pixels) was used for training and the remaining $3.02 \mathrm{Km}^{2}$ (3369 pixels) was used for validation.

The characterization and landslide distribution mapping in the study area were done through intensive fieldwork with the help of Google Earth image interpretation. Generally, areas with flat to gentle slopes were considered to have low or no landslide occurrence. A high density of landslides was found in the central, northeastern, northwestern, southeastern and southwestern parts of the study area. Landslides in this area are predominantly distributed following basalt and limestone ridges/cliffs. The most common types of landslides that are found in the study area include earth slide (rotational and translational slide), debris slide, debris flow, rock fall, topple, rock slide, creep and complex ones as show in Fig. 5. The common landslide types, their causes and effects will be described in the following sections.

The southeastern part of the study area that include Kabi Derami, Golelcha and Dada Gimbel Villages are highly affected by different types of landslides. This area is characterized by undulating physiography and covered by moderately to highly weathered basalt, colluvial deposit (basalt origin) and residual soil deposit. Mostly, landslides in this area are caused by road undercutting, steep slope, high degree of weathering, geological structures (faults and joints), groundwater and active erosion. From field survey, most of the recorded landslides occurred within colluvial material, weathered basalt and barren land. Most of the landslides in this area have a width of $8-273 \mathrm{~m}$, depth of $2-12 \mathrm{~m}$, depletion zone of $3-25 \mathrm{~m}$, length of 20-187 $\mathrm{m}$ and an accumulation zone of $5-50 \mathrm{~m}$. During field study, the depths of failure surface were estimated based on the size and length of landslide and types of slope material. The debris slides, rotational and translational earth slides, debris flow, rock fall and topple are the typical landslides found in this area. Consequently, these landslides damaged large cultivated land, grassland and constructed road. A crack on the failed slope and new crack out of the failed slope followed by spring discharge are also indicators of a future landslide in this area.

Menelego, Were Cheri and Were Bu'i localities in the southwestern part of the study area were affected by landslide incidences. This area is mainly characterized by limestone cliffs that are highly jointed with active gully erosion and weathering. Mostly the study area is covered by limestone, residual soil and colluvial deposit. Earth slide (rotational and translational slide), rock fall, rock slide and wedge failure are common types of landslides in this area. Most of the landslides occurred at the base of limestone cliffs where possible faults are 


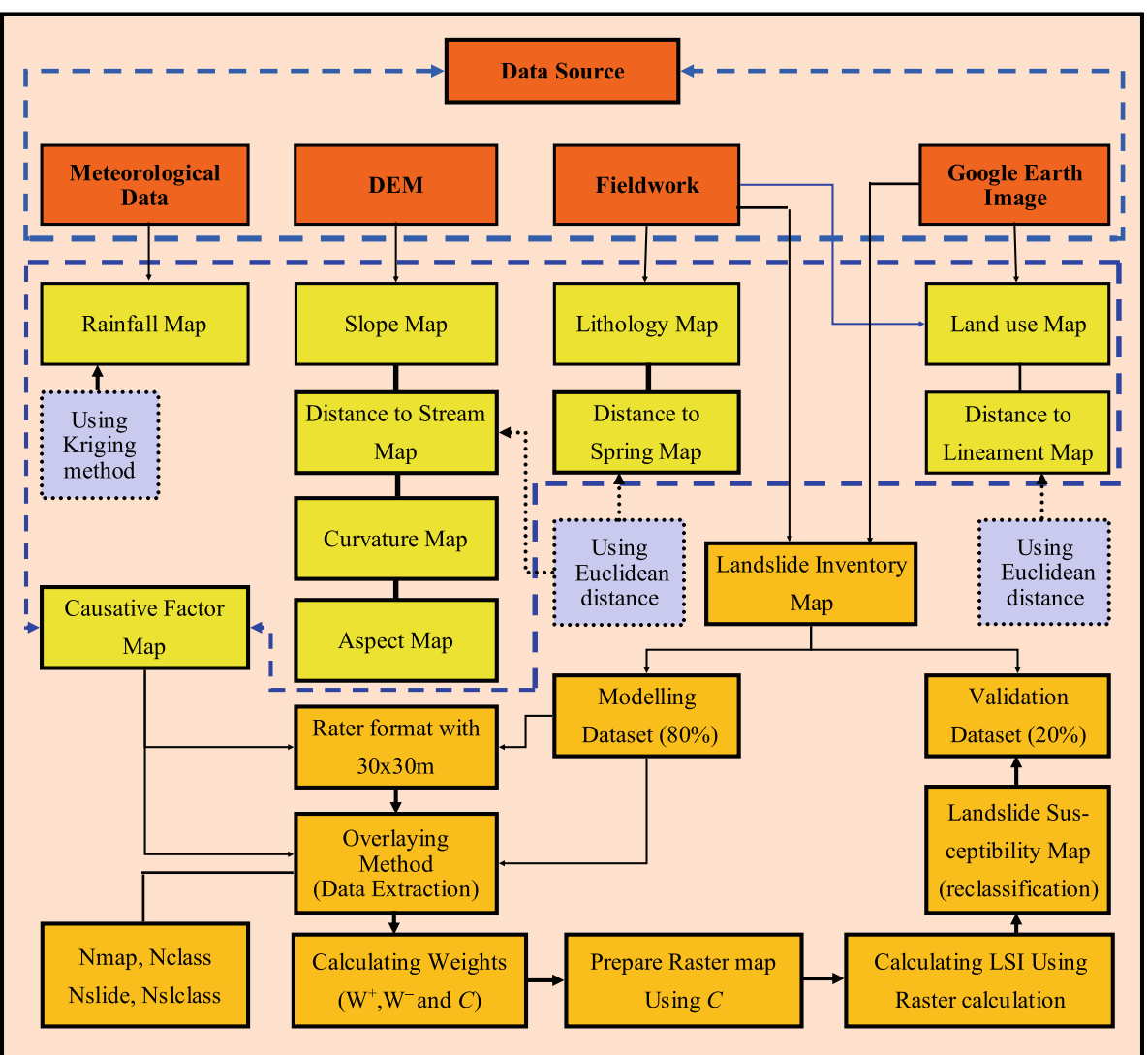

Fig. 4 The general methodological framework of the study

encountered. These landslides have damaged agricultural land and affected the natural vegetation.

The northwester part of the study area comprises Gebro Beresa, Gebro Asmare and Gorba villages and it is an area of high spring discharge and affected by large earth and rock slides. Residual soil, limestone and colluvial deposit are the geological formations found in these villages. According to an informal interview from local people landslides in this area has occurred repeatedly at the end of August i.e. during the rainy season. This indicates that heavy rainfall is the main triggering factor especially on residual soil deposit. Concavity, presence of geological structures (lineaments), groundwater and man-made activity were the main landslide controlling factors. This area consists of large and small scale earth slides, earth flow, rock fall, topple and rock slide. The largest landslide has a width of $601 \mathrm{~m}$, a length of $975 \mathrm{~m}$ length, a height of $151 \mathrm{~m}$ and with a main scarp height of 5-10 m. Approximately, the depletion and accumulation zones have a length of $150 \mathrm{~m}$ and $100 \mathrm{~m}$ long respectively. Most of the landslides were characterized by a width of 5-8 $\mathrm{m}$, a length of 10-14 $\mathrm{m}$ and a height of $12-15 \mathrm{~m}$. Landslide in this area damaged roads, agricultural land, crop and houses.
The northeastern part of the study area including Birje Golelcha, Dembi Birje and Ambisa Villages are characterized by a cliff forming limestone and black soil on top of the cliff covering the flat area. The main causes of landslide occurrence in this specific area are stream and river undercutting, lineaments in the limestone and spring water. The most common types of landslides that were observed in this area are earth slide, rockslide, rock fall and topple. As a result, crops were damaged by an active landslide and most of the farmland areas became unworkable.

Giranyi Mukecha, Mestawet and Sekeyo villages, which are found in the central parts of the study area, are mainly affected by road cutting. Weathered basalt, colluvial and residual soil deposits are the dominant lithologic units covering the area. In addition to road cutting, this area is characterized by high degree of weathering and steep slope with a highly elevated area. As a result, rock fall, rock topple, rock slide and creep are the common landslides in this area. Weathered basalt, colluvial and residual soil deposit are the dominant lithologic units covering the area. This area showed evidence of active and old landslide traces. The presence of an active landslide was shown on the surface by new 

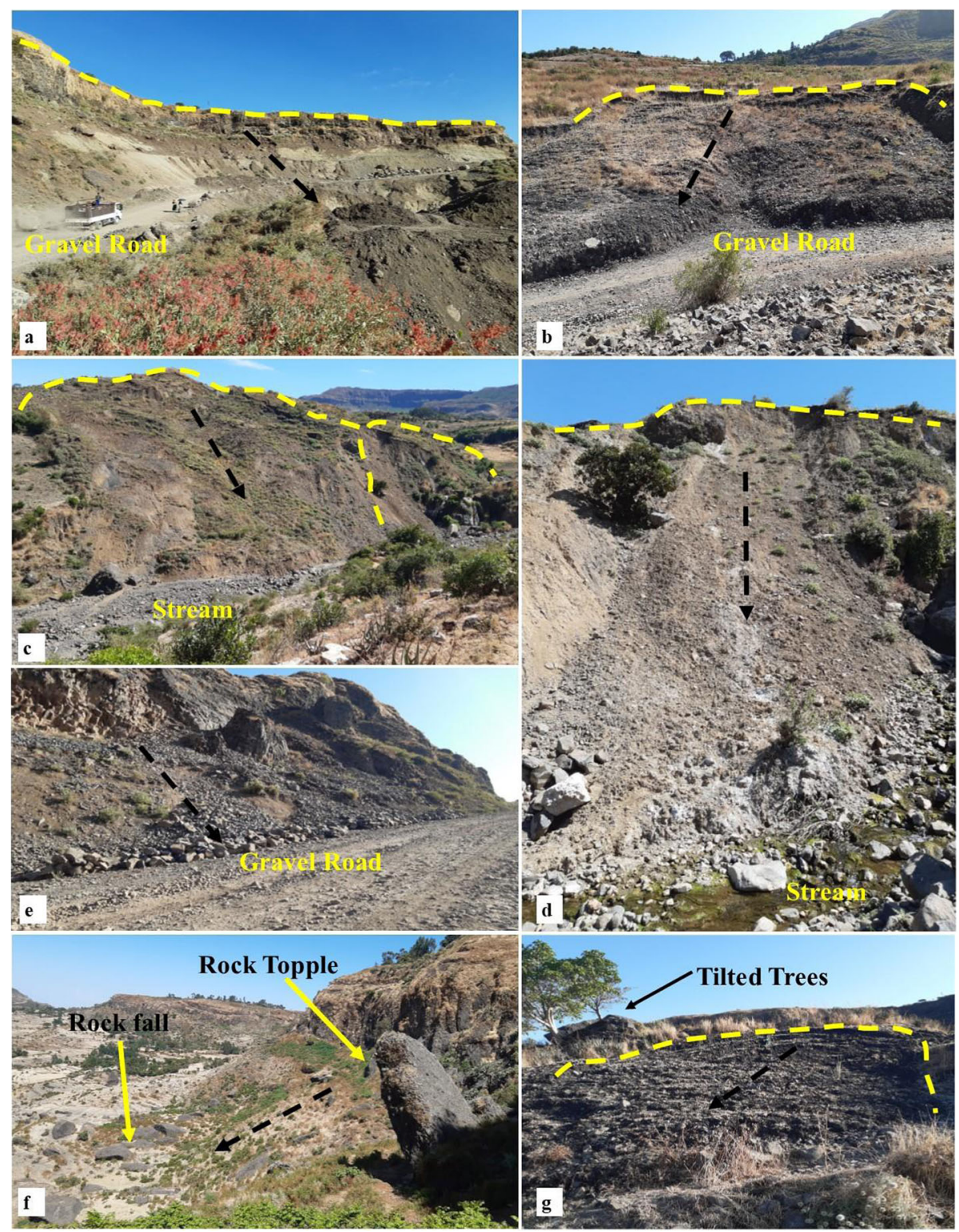

Fig. 5 Field photos illustrating different landslide types. Yellow dotted lines indicate the main scarp of a landslide and black dotted line indicates direction of the slide. a Debris slide (b) Lateral spread (c) Earth slide (d) Debris flow (e) Rock slide (f) Rockfall and Topple and (g) Creep

slope crack development, upper slope (old landslide) tensional crack development, the emergence of spring and tilted vegetation.

\section{Landslide causative factors}

According to Ayalew (1999) landslides occur as a result of adverse natural and/or artificial conditions. The Ethiopian highland is characterized by a steep slope, concave segments as well as the presence of highly jointed and weathered rocks and the action of both rivers and man. Most landslides occurred and reactivated in every rainfall season in the study area; especially along stream banks and in thick black soil exposures. Most of the highlands of Ethiopia are vulnerable to slope instability. Landslide susceptibility map depends on the complex association of slope movements and their causative factors. The causative factors, which were taken into account for the assessment of the landslide susceptibility mapping, were prepared based on the data from literature review and detailed field observation. In the case of landslide susceptibility mapping, there is no standard to select which factor to be used or not, rather this depends on 
the nature of area and data availability (Ayalew and Yamagishi 2005). On this basis, the nine landslide causative factors such as slope, aspect, curvature, lithology, rainfall land use/land cover, distance to spring, distance to lineaments and distance to stream were selected in this study. Distance to road network was excluded as there is no sufficient road network in the study area i.e. only a single road is found.

All the selected causative factors were also used in landslide susceptibility and hazard mapping by many researchers (Raghuvanshi et al. 2014); Raghuvanshi et al. 2015). The study area is characterized by variable lithology which is the main inherent influencing factor. The geomorphological factors such as slope, aspect and curvature are contributing to the initiation of instability and these are used for landslide susceptibility mapping in many researches. Various landslides were also associated with lineament and numerous springs were also discharging on the failed slope sections. The contribution of each landslide causative factor was evaluated and discussed in detail as follows.

\section{Slope}

Slope is considered as a key factor for GIS-based landslide susceptibility mapping (Guzzetti et al. 1999; Dai and Lee 2002). It is one of the most controlling factors of a landslide that affects the concentration of moisture and the level of pore pressure at a local scale and it controls regional hydraulic continuity at larger scales (Ayalew and Yamagishi 2005). The slope gradient was derived from DEM data with a spatial resolution of $30 \mathrm{~m}$ by $30 \mathrm{~m}$. The slope gradient was reclassified similar to Anbalagan (1992). The slope data was reclassified into six classes of $<5^{\circ}, 5-15^{\circ}, 15-25^{\circ}, 25-35^{\circ}, 35-45^{\circ}$ and $>45^{\circ}$ as shown in Fig. 6a. It was reclassified in this way to evaluate the effect of the slope with optimum class intervals. Landslide inventory data showed an increasing trend of past landslide occurrences at steep slopes (Fig. 7). From past landslide distribution data, $61.7 \%$ of the landslides occurred in the slope class $>45^{\circ}$. The past landslide data showed that most susceptible slopes in the study area fall under steep slopes of limestone and basalt cliffs. Rock slope failures like rockslide and rockfall were the most common types of slope failures in steep slopes and this was confirmed during the field observation. More than $84 \%$ of landslides in the study area fall in slopes $>25^{\circ}$.

\section{Aspect}

Slope aspect is referred to as the direction of maximum slope of the terrain surface (Dai et al. 2002; Kumar et al. 2008). Exposure of the terrain aspect to sunlight, wind, rainfall and wave controls the moisture content of soils, degree of weathering and rainfall intensity (Huang et al. 2015). For this study, the slope aspect was derived from
DEM data with a spatial resolution of $30 \mathrm{~m}$. It was generated in ArcGIS using the spatial analyst tools of "surface" function and it was reclassified into 9 classes: Flat $\left(-1^{\circ}\right)$, North $\left(337.5-360^{\circ}\right.$ and $\left.0-22.5^{\circ}\right)$, Northeast (22.5$\left.67.5^{\circ}\right)$, East $\left(67.5-112.5^{\circ}\right)$, Southeast $\left(112.5-157.5^{\circ}\right)$, South $\left(157.5-202.5^{\circ}\right)$, Southwest $\left(202.5-247.5^{\circ}\right)$, West $\left(247.5-292.5^{\circ}\right)$ and Northwest (292.5-337.5 ${ }^{\circ}$ ) (Fig. 6b). The highest landslide density in the study area is found in the west (15.2\%) and northwest (14.4\%) followed by southwest (14.1\%) and north (11.2\%) which may be due to favorable orientation of lineaments and the occurrence of high discharge springs in these aspect classes.

\section{Curvature}

The shape of the slope plays a great role in causing landslide as it has a strong influence on creating slope instability (Gadtaula and Dhakal 2019). Concave and convex curvatures that covered $71 \%$ of the study area influence the stability of slopes. The curvature map of the study area was prepared from DEM data with $30 \mathrm{~m}$ spatial resolution. In this study, total curvature was used (i.e. combination of plan and profile curvature) and It was classified into three classes; concave or negative curvature (-5.45 - -0.01), flat (-0.01-0.01) and convex or positive curvature (0.01-4.78) as shown in Fig. 6c. The distribution of landslides showed a higher percentage of landslides in the concave curvature class accounting for $39.2 \%$. This is due to concentration of water in concave slopes which increase the degree of saturation in a slope.

\section{Lithology}

The geological formation has a significant influence on landslide occurrence (Ayalew and Yamagishi 2005). According to these authors, lithological and structural variations often lead to a difference in strength and permeability of rocks and soils. The study area contains seven lithological units including limestone, sandstone, highly weathered basalt, moderately weathered basalt, residual soil deposit, alluvial deposit and colluvial deposit (Fig. 6d). In the study area, $81.7 \%$ of the total area was covered by weathered basalt and limestone. These units are located at higher and lower elevations of the study area respectively. The past landslide distribution also showed that $49 \%$ of the landslides were concentrated in these 2 units. The remaining $51 \%$ of the landslides were found in the remaining 5 units. The basalt unit was highly weathered and affected by different geological structures that make it susceptible to slope movement by reducing the shear strength of slope materials. Moreover, this unit was also grouped under high productive aquifer which is the source for most springs. About $35.4 \%$ of the past landslides were distributed within moderately weathered basalt and $27.3 \%$ in 


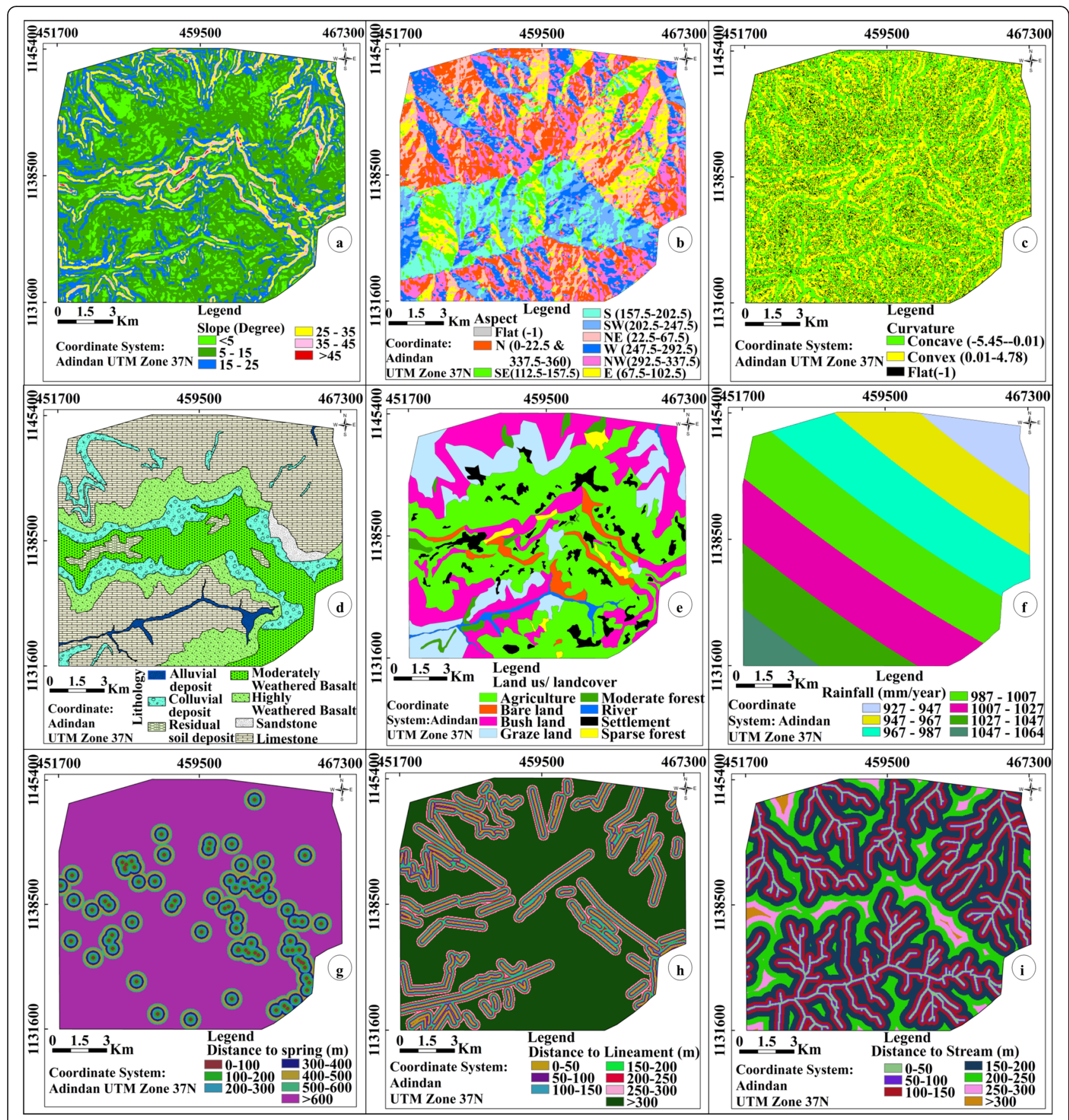

Fig. 6 Landslide causative factor maps: a Slope (b) Aspect (c) Curvature (d) Lithology (e) Land use/Land cover (f) Rainfall (g) Distance to spring (h) Distance to lineament (i) Distance to stream

alluvial deposits as shown in Fig. 7. These landslide distributions in the colluvial deposit and limestone accounted for $14.8 \%$ and $13.7 \%$ respectively. The occurrence of high landslide density in the moderately weathered basalt may be due to steep slope, high degree of weathering and presence of springs. The low concentration of landslide within highly weathered basalt is due to its flat topography.

\section{Land use/land cover}

Land use is also one of the key factors that initiate landslides. Among the land use classes, barren land is highly prone to landslide occurrence. The presence of vegetation is important in slope stability due to its adherence and bonding of slope materials (Mathew et al. 2007). The vegetated area is less affected by landslide problems as it prevents erosion by the natural anchorage of plant 


\begin{tabular}{|c|c|c|c|}
\hline \multirow{2}{*}{$\begin{array}{l}\text { Causative } \\
\text { Factor Class }\end{array}$} & Percentage of Landslide & \multirow{2}{*}{$\begin{array}{l}\text { Causative } \\
\text { Factor Class }\end{array}$} & Percentage of Landslde \\
\hline & $\begin{array}{lllll}0 & 20 & 40 & 60 & 80\end{array}$ & & $\begin{array}{lll}10 & 20 & 30\end{array}$ \\
\hline Land use/Landcover & & Rainfall (mm/year) & \\
\hline Agricultural Land & $6.6 \%$ & $1047-1064$ & $23.6 \%$ \\
\hline Sparse Forest & $18.3 \%$ & $1027-1047$ & $15.9 \%$ \\
\hline Bare Land & $20.9 \%$ & $1007-1027$ & $7.7 \%$ \\
\hline $\begin{array}{r}\text { Settlement } \\
\text { River }\end{array}$ & $1.2 \%$ & $987-1007$ & $17.2 \%$ \\
\hline $\begin{array}{r}\text { River } \\
\text { Grazing Land }\end{array}$ & $\begin{array}{l}22.2 \% \\
6.4 \%\end{array}$ & $967-987$ & $17.4 \%$ \\
\hline Moderate Forest & $5.7 \%$ & $947-967$ & $8.8 \%$ \\
\hline Bush land & $18.5 \%$ & $927-947$ & $9.5 \%$ \\
\hline Lithology & & Distance to spring(m) & \\
\hline $\begin{array}{r}\text { HW Basalt } \\
\text { Colluvial Deposit }\end{array}$ & \begin{tabular}{|l}
$1.1 \%$ \\
$14.8 \%$
\end{tabular} & $>600$ & $8.7 \%$ \\
\hline MW Basalt & $35.4 \%$ & $500-600$ & $10.2 \%$ \\
\hline Alluvial Deposit & $27.3 \%$ & $400-500$ & $11.8 \%$ \\
\hline Limestone & $13.7 \%$ & $300-400$ & $13.8 \%$ \\
\hline Sandstone & $3.5 \%$ & 200-300 & $15.9 \%$ \\
\hline $\begin{array}{l}\text { Residual Soil. } \\
\text { Curvature }\end{array}$ & $4.2 \%$ & $100-200$ & $18.5 \%$ \\
\hline $\begin{array}{l}\text { Curvature } \\
\text { Convex }\end{array}$ & $31.6 \%$ & $0-100$ & $21.1 \%$ \\
\hline Flat & $22.6 \%$ & Distance to Stream(n) & \\
\hline Concave & $\begin{array}{r}29.2 \% \\
\end{array}$ & $>300$ & $20.4 \%$ \\
\hline $\begin{array}{l}\text { Aspect } \\
\text { North West }\end{array}$ & $14.4 \%$ & $250-300$ & $14.6 \%$ \\
\hline West & $15.2 \%$ & $200-250$ & $15.4 \%$ \\
\hline South West & $14.1 \%$ & $150-200$ & $11.2 \%$ \\
\hline South & $8.9 \%$ & $100-150$ & $10.5 \%$ \\
\hline South East & $6.2 \%$ & $50-100$ & $12.4 \%$ \\
\hline $\begin{array}{r}\text { East } \\
\text { North East }\end{array}$ & \begin{tabular}{|l}
$8.2 \%$ \\
$10.1 \%$ \\
\end{tabular} & $0-50$ & $15.5 \%$ \\
\hline North & $11.2 \%$ & Distance to Lineame & $\mathrm{ht}(\mathrm{m})$ \\
\hline Flat & $4.9 \%$ & $>300$ & $3.2 \%$ \\
\hline Slope(degree) & & $250-300$ & $9.7 \%$ \\
\hline $\begin{array}{r}>45 \\
35-45\end{array}$ & $\begin{array}{r}61.7 \% \\
4610\end{array}$ & $200-250$ & $11.3 \%$ \\
\hline $\begin{array}{l}35-45 \\
25-35\end{array}$ & \begin{tabular}{|l}
$46.1 \%$ \\
$23.6 \%$ \\
\end{tabular} & $150-200$ & $13.2 \%$ \\
\hline $15-25$ & $10.6 \%$ & $100-150$ & $15.1 \%$ \\
\hline $5-15$ & $3.7 \%$ & $50-100$ & $19.5 \%$ \\
\hline$<5$ & $1.6 \%$ & $0-50$ & $28.1 \%$ \\
\hline
\end{tabular}

Fig. 7 Percentage of landslide occurrence in each factor class of the landslide causative factors. Note: HW Basalt = Highly Weathered Basalt and MW Basalt $=$ Moderately Weathered Basalt

roots (Kumar et al. 2008). Land use/land cover map of the area was prepared from Google Earth image analysis supported with field study. It can be grouped into eight classes including moderate forest, sparse forest, bush land, bare land, grass land, agricultural land, riverbed and settlement. The distribution of landslides within the land use types of river bed (course) and barren land showed $22.2 \%$ and $20.9 \%$ of the total landslides in the study area respectively. The lower distribution of landslides was encountered in the land use classes of settlement (1.2\%) (Fig. 7).

\section{Rainfall}

The main triggering factor of slope failures is heavy rainfall (Ayalew 1999; Abebe et al. 2010). Variable topographical, geological, hydrological and land use conditions can affect the slope instability of the Ethiopian highland but most of the landslides were triggered by heavy rainfall (Woldearegay 2013). Landslide occurs when the shear stress is greater than the shear strength of the slope materials. Intense rainfall leads to saturation of the slope materials which is the primary cause of landslides. The shear strength of saturated slope materials decreases due to changes in effective inter-granular cohesion and friction. In addition, the shear stress of saturated slope materials increases due to the added weight and the development of pore water pressure. Most of the landslides occurred at the end of August and September. This indicates that landslide occurrence is directly related to slope saturation due to intense and 
accumulated rainfall during the months of June, July and August (Meten et al. 2015b). The rainfall map of the study area was prepared using kriging method in GIS as rain gauge stations are far from each other. The continuous rainfall map was reclassified into seven classes with $10 \mathrm{~mm} /$ year interval i.e. 927 - $947 \mathrm{~mm} /$ year, 947-967 $\mathrm{mm} /$ year, $967-987 \mathrm{~mm} /$ year, $987-1007 \mathrm{~mm} /$ year, 1007 $1027 \mathrm{~mm} /$ year, $1027-1047 \mathrm{~mm} /$ year, $1047-1064 \mathrm{~mm} /$ year (Fig. 6f). High density of landslides is associated with the high annual rainfall classes. The landslide distribution within the rainfall class of 1047-1064 mm accounted for $23.6 \%$ of the landslides in the study area. The remaining percentages of landslides are distributed in the remaining rainfall classes (Fig. 7).

\section{Distance to spring}

To evaluate the contribution of groundwater in landslide occurrence, springs that are indirect surface manifestations of groundwater, were considered (Anbalagan 1992). Raghuvanshi et al. (2015) stated that spring location and landslides showed a direct relationship. The study area falls into three aquifer zone. These are very low, low to moderate and very high productive aquifer classes. The low to moderate productive and very high productive aquifers belong to the limestone and weathered basalt units respectively. It was shown that most springs emerge from weathered basalt unit and basaltic origin colluvial and residual soil deposits. Moreover, most of the springs were also emerged from the failed slope sections as can be seen from field observations. Spring locations were directly related to landslide locations. From the interview of local people, most springs emanated after the slope failures and the number of springs increases as landslide is reactivated. This showed that spring locations that indicate the relative depth of groundwater will affect the degree of saturation for the slope mass. Abrupt changes in the water level cause the pore water pressure on slopes to increase and mechanical strength of a soil to decrease by washing out soluble cementing substances that lead to slope instability. The distance to spring was reclassified into seven classes with $100 \mathrm{~m}$ interval i.e. $0-100 \mathrm{~m}, 100-200 \mathrm{~m}, 200-300 \mathrm{~m}$, $300-400 \mathrm{~m}, 400-500 \mathrm{~m}, 500-600 \mathrm{~m}$ and $>600 \mathrm{~m}$ (Fig. $6 \mathrm{~g})$. In this study, as the distance to spring decreases, the percentage of landslides also increases. The distance to spring classes of $0-100 \mathrm{~m}$ and $100-200 \mathrm{~m}$ accounted for $21.1 \%$ and $18.5 \%$ of landslides respectively.

\section{Distance to lineament}

Lineaments include tectonic structures and a linear arrangement of geomorphological features that may be continuous or interrupted without any clear evidence of displacement such as topographic break (Ayalew and Yamagishi 2005). The Ethiopian highland is characterized by high relief and rugged topography (deep valleys and gorges with steep slopes) which was developed from large scale Pliocenequaternary uplift (Mohr 1986). As a result, Ethiopian highland was crossed by different structures that give horst, tectonic depression and fault scarp (Korme et al. 2004). The current study area is part of the northwestern Ethiopian highland which has different structures such as faults, fractures and escarpments. The term lineament includes faults, fractures and escarpments. Generally, as the distance to lineament decreases, the potential for slope failure increases. This parameter is a very important controlling factor to evaluate landslide susceptibility (Yilmaz 2009; Conforti et al. 2014). As the number and concentration of geological structures increases, the degree of weathering and fracturing also increases implying a reduction in the strength of slope materials. These structures can be used as a slip/failure surface and conduit for water movement (Conforti et al. 2014). In order to evaluate the influence of lineaments on landslide occurrences, distance to lineament was considered as the main influencing factor and it was extracted from the regional geological map, Google Earth image interpretation and field study. The whole lineament map was further subjected to a GIS buffering analysis by a distance of $50 \mathrm{~m}$ which was then classified into seven classes of $0-50 \mathrm{~m}, 50$ $100 \mathrm{~m}, 100-150 \mathrm{~m}, 150-200 \mathrm{~m}, 200-250 \mathrm{~m}, 250-300 \mathrm{~m}$ and $>300 \mathrm{~m}$. The past landslide density showed an increasing trend as distance to lineament decreases (Fig. 7). For instance, $28.1 \%$ of the landslides in the study area fall in the distance to lineament class of $0-50 \mathrm{~m}$.

\section{Distance to stream}

Landslide occurrence was also controlled by proximity to drainage and drainage density (Kumar and Anbalagan 2019). Active river or stream incision has a significant influence on slope instability through toe erosion and saturation of the slope materials there by causing further slope steepening and instability (Mathew et al. 2007; Abebe et al. 2010). The stream map has been extracted from DEM and the distance to stream map was prepared by Euclidean distance buffering with a $50 \mathrm{~m}$ buffer distance which was then classified into seven classes of $0-50 \mathrm{~m}, 50$ - $100 \mathrm{~m}, 100-150 \mathrm{~m}, 150-200 \mathrm{~m}, 200-250 \mathrm{~m}, 250-300$ $\mathrm{m}$ and $>300 \mathrm{~m}$ (Fig. 6i). The last class comprises of high percentage of landslides and the distance to stream in this class didn't show a direct relation with landslides. The reason for the high density of landslides in a distance to stream class of $>300 \mathrm{~m}$ may be due to the combined effect of other factors that favored landslide occurrence (Ayalew and Yamagishi 2004; Raghuvanshi et al. 2014).

\section{Result and discussion}

Relationship between landslide and causative factors

In this study the relationship between landslides and each causative factor's class was established. The 
significance of each causative factor class can be determined based on the weights of evidence model. According to Bonham-Carter et al. (1989), the landslide susceptibility weights between 0.1 and 0.5 have middle predictive, 0.5 and 1 are moderately predictive, 1 and 2 are strongly predictive and greater than 2 are extremely predictive. The extremely predictive slope classes $>45^{\circ}$ and $35^{\circ}-45^{\circ}$ have a positive weights $\left(\mathrm{W}^{+}\right)$of 2.572 and 2.085 respectively while the strongly predictive slope class of $25^{\circ}-35^{\circ}$ has $\mathrm{W}^{+}$value of 1.191 . From the lithologic map of the area, the moderately weathered basalt and alluvial deposit fall in a moderately predictive class with $\mathrm{W}^{+}$of 0.927 and 0.631 respectively. From land use/ land cover factor map, the bare land, river and bush land fall in a moderately predictive class of landslide susceptibility with $\mathrm{W}^{+}$values of $0.898,0.837$ and 0.708 respectively. For the distance to lineament, the strongly predictive class is $0-50 \mathrm{~m}$ with $\mathrm{W}^{+}=1.344$ followed by moderately predictive classes of $50-100 \mathrm{~m}, 100-150 \mathrm{~m}$ and $150-200 \mathrm{~m}$ with $\mathrm{W}^{+}=0.906,0.610$ and 0.462 respectively. For the factor map of distance to spring, the moderately predictive classes are $0-100 \mathrm{~m}, 100-200 \mathrm{~m}$ and $200-300 \mathrm{~m}$ with $\mathrm{W}^{+}=0.818,0.666$ and 0.498 respectively. The moderate predictive class of rainfall includes $1047-1064 \mathrm{~mm} /$ year with $\mathrm{W}^{+}=0.593$. In general, many of the factor classes fall in the middle predictive classes of Bonham-Carter et al. (1989) (Table 1). The spatial association between factor classes and the occurrence of the landslide was quantified by weights of contrast. The positive weight value indicates a positive spatial association while the negative ones have a negative spatial association.

\section{Relationship between landslide and topographic parameters}

The slope of the study area was classified into six classes and the contribution of each class was determined. As the steepness of the slope increases, the probability of landslide occurrence also increases (Lee and Min 2001). Generally, as the slope angle increases, the driving force of the slope mass also increases but the resistive force decreases (Mahdadi et al. 2018). The result obtained from this study also verified this claim. As discussed previously, the slope class $>45$ contains $61.7 \%$ of the landslides which indicates a high probability of landslide occurrence. This class showed a high significance $(C=$ $2.585)$ followed by slope classes $35-45^{\circ}$ and $25-35^{\circ}(C=$ 1.439 and 2.209, respectively). The slope classes above $15^{\circ}$ indicated positive $C$ values that showed a positive correlation between landslide and factor classes. The remaining classes below $15^{\circ}$ showed negative weights and a negative correlation.

In the case of aspect classes, the W, NW and SW slope faces have shown a positive correlation between landslide and each factor class with $C=0.355,0.294$ and 0.251 respectively. This indicated that most of the slopes facing towards the west direction have a high probability of landslide occurrence as it is mainly affected by stream erosion, geological structures (lineaments) and high discharge springs. This is due to the fact that most of streams and springs are flowing in this direction. The remaining classes showed a negative correlation (Table 1).

Curvature is the key factor that controls the flow of groundwater and surface water. Concave classes showed a positive correlation with $C=0.303$. This may be due to the high groundwater discharge and erosion activity in this area. The weight of this class also indicated a high probability of landslide occurrence. The remaining classes showed a negative correlation as shown in Table 1.

\section{Relationship of landslide with lithology, land use and rainfall}

The higher percentages of landslides have occurred within moderately weathered basalt, alluvial deposit, colluvial deposit and limestone as shown in Fig. 7. As a result, the higher probability of landslide occurrence will be expected in these factor classes. Moderately weathered basalt showed the highest values of $C=1.246$ followed by alluvial deposit $(C=0.645)$. The remaining classes i.e. residual soil, limestone, colluvial deposit, highly weathered basalt and sandstone have shown negative weights of contrast values with a negative association.

In case of land use/land cover, a high probability of landslides will occur in the bushland $(C=1.009)$, river $(C=$ $0.866)$, bare land $(C=0.826)$ and sparse forest $(C=0.644)$ classes with a decreasing order of weights of contrast. The remaining classes are characterized by negative $C$ values with negative correlation. This is because bare land and bushland are occupying the steep slopes of highly weathered basalt and limestone. In addition to the bare land, the sparsely forested area is favorable for water saturation and active erosion that make it susceptible to landslides. The river bed has an area of active erosional activity.

The landslide incidence increase as rainfall intensity increases (Anis et al. 2019). The current study also confirmed this scenario with some exceptions. The rainfall classes of 1047-1067 and 1027-1047 mm/year revealed high landslide occurrence with high contrast values of $C=0.619$ and 0.181 respectively. The last four rainfall classes showed a progressive increase in the probability of landslide occurrence except for the interruption of one class i.e. $1007-1027 \mathrm{~mm} /$ year which has a negative weight of contrast value.

\section{Relationship between landslide and distances to lineament, stream and spring}

The distances to lineaments and springs showed an increasing probability of landslide occurrence as distances 
Table 1 The input data used in the analyses and results obtained from Weights of Evidence model

\begin{tabular}{|c|c|c|c|c|c|c|c|c|c|}
\hline Factors & Class & Nclass & Npix1 = Nslclass & Npix2 & Npix3 & Npix4 & W+ & W- & $\mathrm{C}$ \\
\hline \multirow[t]{6}{*}{ Slope (degree) } & $<5$ & 29,863 & 361 & 13,043 & 29,502 & 178,848 & -1.660 & 0.125 & -1.785 \\
\hline & $5-15$ & 111,669 & 3096 & 10,308 & 108,573 & 99,777 & -0.814 & 0.474 & -1.287 \\
\hline & $15-25$ & 52,516 & 4131 & 9273 & 48,385 & 159,965 & 0.283 & -0.104 & 0.387 \\
\hline & $25-35$ & 22,125 & 3864 & 9540 & 18,261 & 190,089 & 1.191 & -0.248 & 1.439 \\
\hline & $35-45$ & 5161 & 1760 & 11,644 & 3401 & 204,949 & 2.085 & -0.124 & 2.209 \\
\hline & $>45$ & 420 & 192 & 13,212 & 228 & 208,122 & 2.572 & -0.013 & 2.585 \\
\hline \multirow[t]{9}{*}{ Aspect } & Flat $(-1)$ & 77 & 2 & 13,404 & 76 & 208,274 & -0.894 & 0.000 & -0.894 \\
\hline & $N(0-22.5 \& 337.5-360)$ & 41,881 & 2462 & 10,943 & 39,419 & 168,931 & -0.030 & 0.007 & -0.036 \\
\hline & NE (22.5-67.5) & 31,906 & 1698 & 11,707 & 30,208 & 178,142 & -0.135 & 0.021 & -0.156 \\
\hline & $E(67.5-102.5)$ & 22,465 & 975 & 12,430 & 21,490 & 186,860 & -0.349 & 0.033 & -0.383 \\
\hline & SE (112.5-157.5) & 16,473 & 539 & 12,866 & 15,934 & 192,416 & -0.643 & 0.039 & -0.681 \\
\hline & S (157.5-202.5) & 21,183 & 990 & 12,415 & 20,193 & 188,157 & -0.272 & 0.025 & -0.297 \\
\hline & SW (202.5-247.5) & 23,047 & 1714 & 11,691 & 21,333 & 187,017 & 0.222 & -0.029 & 0.251 \\
\hline & W (247.5-292.5) & 28,770 & 2304 & 11,101 & 26,466 & 181,884 & 0.302 & -0.053 & 0.355 \\
\hline & NW (292.5-337.5) & 35,953 & 2721 & 10,684 & 33,232 & 175,118 & 0.241 & -0.053 & 0.294 \\
\hline \multirow[t]{3}{*}{ Curvature } & Concave (-5.45--0.01) & 95,953 & 6749 & 6656 & 89,204 & 119,146 & 0.162 & -0.141 & 0.303 \\
\hline & Flat $(-0.01-0.01)$ & 30,095 & 1220 & 12,185 & 28,875 & 179,475 & -0.421 & 0.054 & -0.474 \\
\hline & Convex (0.01-4.78) & 95,707 & 5436 & 7969 & 90,271 & 118,079 & -0.066 & 0.048 & -0.114 \\
\hline \multirow[t]{7}{*}{ lithology } & Residual soil deposit & 4418 & 74 & 13,331 & 4344 & 204,003 & -1.329 & 0.016 & -1.344 \\
\hline & Sandstone & 3068 & 42 & 13,363 & 3026 & 205,321 & -1.534 & 0.011 & -1.545 \\
\hline & Limestone & 108,975 & 5877 & 7528 & 103,098 & 105,249 & -0.121 & 0.106 & -0.227 \\
\hline & Alluvial deposit & 3568 & 385 & 13,020 & 3183 & 205,164 & 0.631 & -0.014 & 0.645 \\
\hline & MW Basalt & 36,834 & 5149 & 8256 & 31,685 & 176,662 & 0.927 & -0.320 & 1.246 \\
\hline & Colluvial deposit & 29,493 & 1728 & 11,677 & 27,765 & 180,582 & -0.033 & 0.005 & -0.038 \\
\hline & HW Basalt & 35,396 & 150 & 13,255 & 35,246 & 173,101 & -2.716 & 0.174 & -2.890 \\
\hline \multirow[t]{7}{*}{ Land use/land cover } & Bush Land & 46,816 & 5408 & 7997 & 41,408 & 166,942 & 0.708 & -0.295 & 1.003 \\
\hline & Moderately Vegetated Forest & 5739 & 119 & 13,286 & 5620 & 202,730 & -1.111 & 0.018 & -1.130 \\
\hline & Grazing Land & 35,835 & 1725 & 11,680 & 34,110 & 174,240 & -0.241 & 0.041 & -0.282 \\
\hline & River & 3123 & 404 & 13,001 & 2719 & 205,631 & 0.837 & -0.017 & 0.854 \\
\hline & Settlement & 12,646 & 74 & 13,331 & 12,572 & 195,778 & -2.392 & 0.057 & -2.448 \\
\hline & Bare Land & 11,970 & 1632 & 11,773 & 10,338 & 198,012 & 0.898 & -0.079 & 0.976 \\
\hline & Agricultural Land & 105,626 & 4043 & 9362 & 101,583 & 106,767 & -0.480 & 0.310 & -0.790 \\
\hline \multirow[t]{7}{*}{ Distance to lineament $(\mathrm{m})$} & $0-50$ & 16,723 & 3309 & 10,096 & 13,414 & 194,936 & 1.344 & -0.217 & 1.561 \\
\hline & $50-100$ & 16,381 & 2249 & 11,156 & 14,132 & 194,218 & 0.906 & -0.113 & 1.019 \\
\hline & $100-150$ & 16,100 & 1705 & 11,700 & 14,395 & 193,955 & 0.610 & -0.064 & 0.675 \\
\hline & $150-200$ & 12,332 & 1143 & 12,262 & 11,189 & 197,161 & 0.462 & -0.034 & 0.496 \\
\hline & $200-250$ & 14,409 & 1143 & 12,262 & 13,266 & 195,084 & 0.292 & -0.023 & 0.315 \\
\hline & $250-300$ & 12,849 & 877 & 12,528 & 11,972 & 196,378 & 0.130 & -0.008 & 0.138 \\
\hline & $>300$ & 132,961 & 2979 & 10,426 & 129,982 & 78,368 & -1.032 & 0.726 & -1.759 \\
\hline \multirow[t]{5}{*}{ Distance to stream (m) } & $0-50$ & 44,548 & 2890 & 10,515 & 41,658 & 166,691 & 0.075 & -0.020 & 0.095 \\
\hline & 50-100 & 36,022 & 1876 & 11,529 & 34,146 & 174,203 & -0.158 & 0.028 & -0.186 \\
\hline & $100-150$ & 35,312 & 1554 & 11,851 & 33,758 & 174,591 & -0.335 & 0.054 & -0.388 \\
\hline & $150-200$ & 26,348 & 1234 & 12,171 & 25,114 & 183,235 & -0.270 & 0.032 & -0.301 \\
\hline & $200-250$ & 24,021 & 1546 & 11,859 & 22,475 & 185,874 & 0.067 & -0.008 & 0.075 \\
\hline
\end{tabular}


Table 1 The input data used in the analyses and results obtained from Weights of Evidence model (Continued)

\begin{tabular}{|c|c|c|c|c|c|c|c|c|c|}
\hline Factors & Class & Nclass & Npix1 = Nslclass & Npix2 & Npix3 & Npix4 & W+ & W- & C \\
\hline & $250-300$ & 18,460 & 1132 & 12,273 & 17,328 & 191,021 & 0.015 & -0.001 & 0.017 \\
\hline & $>300$ & 37,043 & 3173 & 10,232 & 33,870 & 174,479 & 0.376 & -0.093 & 0.468 \\
\hline \multirow[t]{7}{*}{ Distance to spring (m) } & $0-100$ & 2774 & 353 & 13,052 & 2421 & 205,928 & 0.818 & -0.015 & 0.833 \\
\hline & 100-200 & 6755 & 752 & 12,653 & 6003 & 202,346 & 0.666 & -0.028 & 0.695 \\
\hline & $200-300$ & 10,341 & 990 & 12,415 & 9351 & 198,998 & 0.498 & -0.031 & 0.529 \\
\hline & $300-400$ & 11,389 & 947 & 12,458 & 10,442 & 197,907 & 0.343 & -0.022 & 0.365 \\
\hline & $400-500$ & 13,739 & 978 & 12,427 & 12,761 & 195,588 & 0.175 & -0.013 & 0.187 \\
\hline & $500-600$ & 14,082 & 863 & 12,542 & 13,219 & 195,130 & 0.015 & -0.001 & 0.016 \\
\hline & $>600$ & 162,674 & 8522 & 4883 & 154,152 & 54,197 & -0.152 & 0.337 & -0.488 \\
\hline \multirow[t]{7}{*}{ Rainfall (mm/year) } & $927-947$ & 12,275 & 513 & 12,892 & 11,762 & 196,547 & -0.389 & 0.019 & -0.408 \\
\hline & $947-967$ & 33,327 & 1297 & 12,108 & 32,030 & 176,279 & -0.463 & 0.065 & -0.528 \\
\hline & 967-987 & 46,191 & 3557 & 9848 & 42,634 & 165,675 & 0.260 & -0.079 & 0.339 \\
\hline & 987-1007 & 51,152 & 3880 & 9525 & 47,272 & 161,037 & 0.243 & -0.084 & 0.328 \\
\hline & $1007-1027$ & 44,816 & 1532 & 11,873 & 43,284 & 165,025 & -0.598 & 0.112 & -0.709 \\
\hline & $1027-1047$ & 26,741 & 1874 & 11,531 & 24,867 & 183,442 & 0.158 & -0.023 & 0.181 \\
\hline & 1047-1064 & 7212 & 752 & 12,653 & 6460 & 201,849 & 0.593 & -0.026 & 0.619 \\
\hline
\end{tabular}

Note: A total number of pixels with a landslide (Nslide $=13,405)$ and the total number of pixels within a map $(\mathrm{Nmap}=221,754)$

to lineaments and springs decrease. The factor classes of both parameters also showed a positive association with the highest weights of contrast $(C)$ values of 1.561 and 0.833 respectively except in the last factor classes. When the lineaments are overlaid with landslide susceptibility map, the high and very high landslide susceptible zones are found in areas of high lineament density.

The distance to stream classes didn't show a good correlation with landslides as distance to stream decreases. The occurrence of landslides was higher in the last class with distance to stream class $>300 \mathrm{~m}$ followed by the first distance to stream class of $0-50 \mathrm{~m}$.

\section{Landslide susceptibility mapping using weights of evidence model}

Landslide susceptibility index can be calculated based on the overall spatial association between the nine causative factors and training landslides. In this study, the total number of landslide pixels is 16,774 and the total number of pixels within the entire area is 221,754 . These landslide and area pixels were classified into different factor classes to develop and validate the landslide susceptibility map. Weight of each factor class was calculated based on the density of landslides within each factor class. The positive and negative weights of each factor class were calculated based on Eqs. 3 and 4. The weight of contrast values of all factors including slope, curvature, aspect, lithology, land use/land cover, rainfall, distance to stream, distance to spring and distance to lineament were calculated. Weight of contrast is the difference between positive and negative weight values.
Raster maps of all the nine causative factors were prepared using weights of contrast values which were then integrated using a raster calculator of the spatial analyst tool in ArcGIS to produce the landslide susceptibility index (LSI) map. The final landslide susceptibility index map was prepared based on Eq. 8 as follows.

$$
\begin{aligned}
L S I= & \boldsymbol{C}_{\text {slope }}+\boldsymbol{C}_{\text {aspect }}+\boldsymbol{C}_{\text {curvature }}+\boldsymbol{C}_{\text {lithology }} \\
& +\boldsymbol{C}_{\text {landuse }}+\boldsymbol{C}_{\text {rainfall }}+\boldsymbol{C}_{\text {dlineament }} \\
& +\boldsymbol{C}_{\text {spring }}+\boldsymbol{C}_{\text {stream }}
\end{aligned}
$$

Where $C_{\text {slope }}=$ weights of contrast value of slope, $C_{\text {as- }}$ pect $=$ weights of contrast value of aspect, $C_{\text {curvature }}=$ weights of contrast value of curvature, $\boldsymbol{C}_{\text {lithology }}=$ weights of contrast value of lithology, $C_{\text {landuse }}=$ weights of contrast value of land use, $C_{\text {rainfall }}=$ weights of contrast value of rainfall, $C_{\text {lineament }}=$ weights of contrast value of distance to lineament, $\boldsymbol{C}_{\text {spring }}=$ weights of contrast value of distance to spring and $\boldsymbol{C}_{\text {stream }}=$ weights of contrast value of distance to stream.

The LSI values range from -11.308 to 7.520 that were reclassified into five landslide susceptibility classes of very low (-11.308 - - 6.106), low (-6.106 - 3.580), moderate $(-3.580--1.117)$, high $(-1.117-1.600)$ and very high (1.600-7.520) using the natural breaks classification method (Fig. 8). The study area covered $199.5 \mathrm{Km}^{2}$ out of which $80.32 \mathrm{Km}^{2}$ falls to the very low and low landslide susceptibility classes that comprised $2.49 \%$ of the landslide density. Landslide density data indicated that 85\% (69.49 $\mathrm{Km}^{2}$ ) of the past landslides occurred in the high and very high landslide susceptibility classes. The remaining $12.48 \%$ 
$\left(49.69 \mathrm{Km}^{2}\right)$ of landslides occurred in a moderate landslide susceptibility class (Table 2).

For more clarification, lineament and lithology maps were overlaid over the landslide susceptible maps. This revealed that high and very high landslide susceptibility zones were areas of high lineament density in moderately weathered basalt and limestone. The weight of contrast value for moderately weathered basalt is higher than that of that of limestone which indicated a higher and lower level of influence respectively in terms of their contribution towards landslide occurrence. Moderate, high and very high landslide susceptible zones in an area of limestone exposures were due to the effect of geologic structure like joint, fault and other linear features. Highly weathered basalt, sandstone and gentle area of limestone fall into low to very low landslide susceptibility zones. But the highly weathered basalt falls completely in the very low susceptibility zone. This unit is exposed in gentle areas where there are no any geologic structures but with the presence of some discharging springs and agricultural practice. Similarly, the limestone exposed in a gentle slope is also free from any geologic structures and falls into the low landslide susceptibility zone.

\section{Validation of the landslide susceptibility model}

Validation of the model is an important procedure to know how the model predicts well. Several approaches were used in the validation of landslide susceptibility maps. The most commonly used ones include the success rate curve, predictive rate curve, landslide percent comparison, landslide density, relative error, relative landslide density index and Receiver operating characteristics curve. For this study, landslide density index, success rate and predictive rate curves were used to check the accuracy of a model.

\section{Area Under the Curve (AUC)}

Validation of the LSM using AUC is divided into success rate and prediction rate curves (Sumatra et al. 2015). The success rate describes how well the model fits with

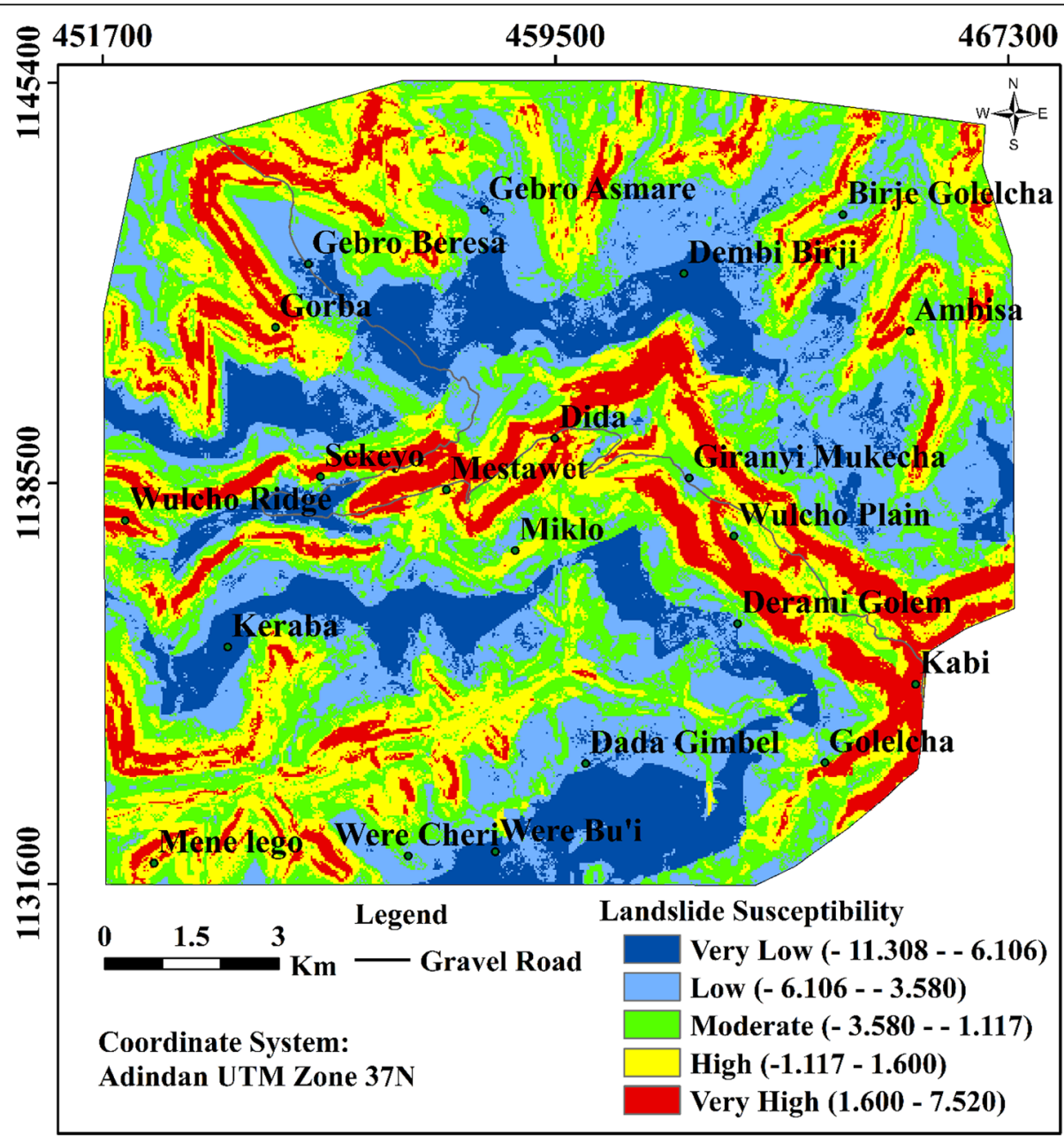

Fig. 8 Landslide susceptibility map of the study area 
Table 2 The relation between training landslides and landslide susceptibility classes

\begin{tabular}{llllll}
\hline Landslide Susceptibility Class (LSI) & NPLSM & \%PLSM & NTLSP & \%TLSP & Area (km2) \\
\hline Very Low (-11.308 - 6.106) & 33,611 & 15.16 & 75 & 0.56 & 30.24 \\
Low (-6.106 - 3.580) & 55,665 & 25.10 & 259 & 1.93 & 50.08 \\
Moderate (-3.580 - 1.117) & 55,230 & 24.91 & 4673 & 12.48 & 49.69 \\
High (-1.117-1.600) & 49,709 & 22.42 & 4929 & 36.77 & 44.72 \\
Very High (1.600-7.520) & 27,532 & 12.42 & 6468 & 48.25 & 24.77
\end{tabular}

Note: LSI Landslide Susceptibility Index, NPLSM Number of Pixels in a Landslide Susceptibility Map, \%PLSM Percent of Pixels in a Landslide Susceptibility Map, NTLSP Number of Training Landslide Pixels, \%TLSP Percent of Training Landslide Pixels

past events and prediction rate describes how well the model predicts landslide occurrence in the future. The success rate curve was prepared by overlaying the training landslide with the landslide susceptibility index (LSI) while the prediction rate curve was obtained by overlaying the validation landslides with LSI map. The LSI values were reclassified into hundred classes and sorted in a descending order. Then the percentage of landslide susceptibility index value is plotted against the percentage of cumulative landslide occurrence to produce the success and predictive rate curves (Fig. 9). The area under the curves was estimated from rate graphs (Lee and Talib 2005; Lee and Sambath 2006). The area under the curve values showed 0.824 and 0.834 for success rate and predictive rate respectively. This showed an accuracy of $82.4 \%$ and $83.4 \%$ for the training and validation models respectively of the landslide susceptibility map indicating that the model has a very good performance.

\section{Landslide Density Index (LDI)}

Based on LDI, the model is considered valid when the landslide density value increases from very low to very high landslide susceptibility classes (Pradhan and Lee 2010). LDI is calculated as the ratio of the percentage of pixels with landslides in landslide susceptibility class to the percentage of pixels within the landslide susceptibility class. When the landslide density index increases from very low to very high landslide susceptibility classes (Table 3), then the resulting landslide susceptibility map is said to be valid. The plotted landslide density graph is used to show the distribution of landslide density in each susceptibility class (Fig. 10). The statistical analysis results obtained from overlay analysis of the training landslides over the landslide susceptibility class indicated that maximum area of landslide distribution was observed in the very high and high susceptibility classes i.e. $48.3 \%$ and $36.8 \%$ respectively followed by moderate $(12.5 \%)$, low $(1.9 \%)$ and very low $(0.6 \%)$ susceptibility classes. Likewise, the validating landslides also showed the maximum landslide distribution in the very high (50.5\%) and high (34.8\%) susceptibility classes followed by moderate (12.9\%), low (1.5\%) and very low (0.2\%) landslide susceptibility classes (Fig. 11).

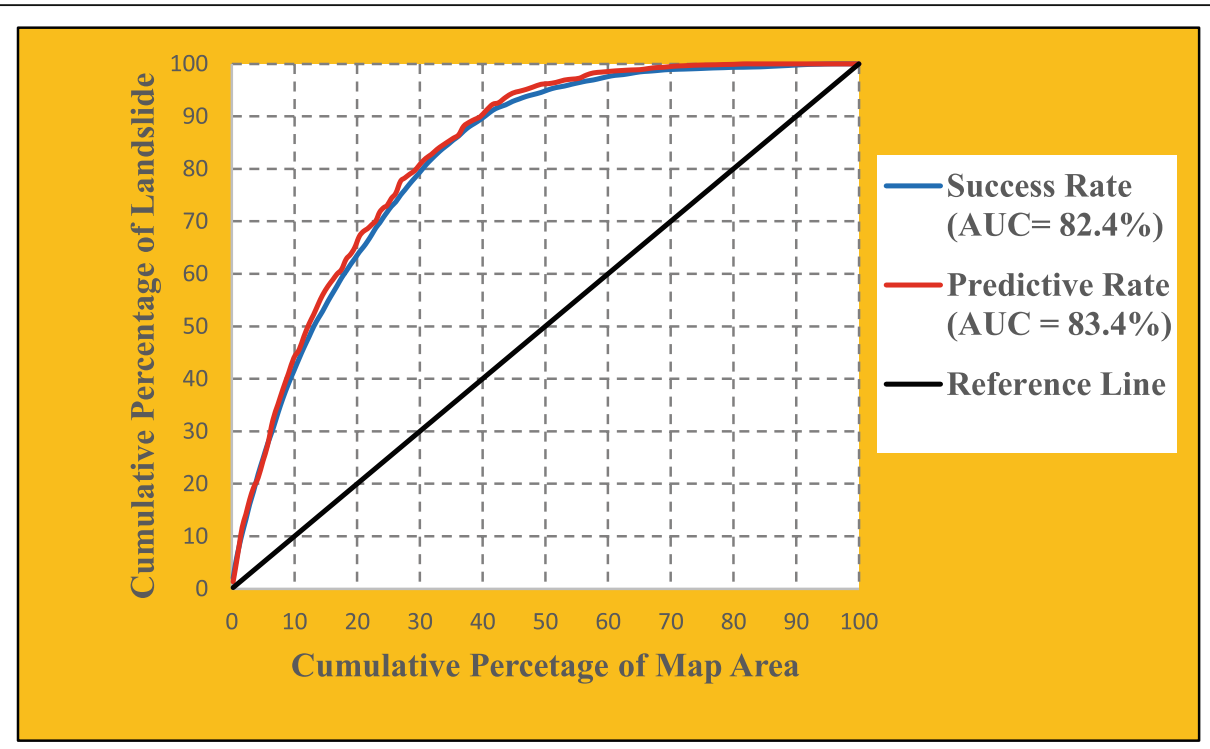

Fig. 9 Success rate and predictive rate curves for weights of evidence model 


\section{Conclusion}

Kabi-Gebro locality of Gundomeskel area is an area where active erosion, rugged and undulating topography is prevailing. This area is highly affected by a landslide problem which is caused by natural and man-made phenomena. The most common types of landslide in the study area include rock slide, earth slide, rock fall, topple, earth flow, rock flow, debris flow, debris slide and creep. Landslides affected the agricultural land, crop, human lives, road and settlement in the study area. Therefore, the landslide susceptibility map was prepared using weights of evidence model which is very important to manage the effect of landslides. For this, 514 landslide locations were identified and classified into training (80\%) and validation landslides (20\%). The spatial association between the training landslides and the nine causative factors such as slope, curvature, aspect, lithology, rainfall, land use, distance to stream, distance to lineament and distance to spring were used for landslide susceptibility mapping. The percentage of landslides was calculated in each factor class to evaluate which factor class is most influencing for landslide occurrence. The landslide distribution data showed the highest percentages in the factor classes of slope $>45^{\circ}(61.7 \%)$, concave curvature (39.2\%), moderately weathered basalt (35.4\%), distance to lineament $(0-50 \mathrm{~m})(28.1 \%)$, rainfall $(1047$ $1064 \mathrm{~mm} /$ year $)(23.6 \%)$, distance to spring $(0-50 \mathrm{~m})$ (21.1\%), bare land $(20.9 \%)$, distance to stream $(>300 \mathrm{~m})$ (20.4\%) and west facing aspect (15.2\%). The weight of contrast value of each factor class was calculated during landslide susceptibility modeling. The slope class $>45^{\circ}$ has an extremely highest influence on landslide occurrence with $C=2.583$. The slope classes $\left(25^{\circ}-35^{\circ}, 35^{\circ}\right.$ $45^{\circ}$ and $>45^{\circ}$ ), lithology class (moderately weathered basalt), land use class (bush land) and distance to lineament classes $(0-50 \mathrm{~m}$ and $50-100 \mathrm{~m})$ have shown the highest and positive weights of contrast values $(C \geq 1)$. These factor classes have a relatively very high influence on landslide occurrence. The other factor classes like lithology (alluvial deposit), land use (bare land, sparse forest and river), distance to lineament (100 - $150 \mathrm{~m}$ and 150 $200 \mathrm{~m})$, distance to spring $(0-100 \mathrm{~m}, 100-200 \mathrm{~m}$ and $200-300 \mathrm{~m})$, distance to stream $(>300 \mathrm{~m})$ and rainfall
(1035 - $1063 \mathrm{~mm} /$ year) have also higher weights of contrast values $(C)$ between 0.5 and 1 . There are many factor classes which have weights of contrast values $(C)$ in between 0 and 0.5 . Finally, a landslide susceptibility map was prepared using a raster calculator of the spatial analyst tool in ArcGIS by adding all weights of contrast values of the nine landslide causative factors. Then, this landslide susceptibility map was reclassified into very low, low, moderate, high and very high susceptibility classes based on natural breaks method. Validating the model is the key issue in any landslide susceptibility mapping. The performance of the model used and the accuracy of the landslide susceptibility map were evaluated using landslide density index and area under the curve (AUC). AUC of the model showed the success rate and predictive rate accuracies of $82.4 \%$ and $83.4 \%$ respectively. This confirms that the weights of evidence model has a very good performance. The landslide density index showed that the percentage of landslides progressively increased from very low to very high landslide susceptibility classes which proved the validity of the landslide susceptibility map. Finally, the weights of evidence model applied in this study was found to be simple, reliable and effective in assessment of numerous causative factors with landslides. Hence, the final landslide susceptibility map from weights of evidence model in this study area can provide firsthand information for decision makers in infrastructure development and land use planning at district, zonal, regional and federal levels.

\section{Recommendation}

The result obtained from this research was important to take proper mitigation measures to prevent the impact of landslide hazard. Providing adequate training for local people on 'how' and 'where' the landslide occurs is very important before any preventive or corrective measures are taken. The main aggravating factors should be minimized by reducing steep slopes along the road section, dewatering high groundwater and managing poor agricultural practices. Planting or encouraging the natural growth of vegetation can also be an effective means of slope stabilization. The plant root is important in controlling erosion and shallow landslide movement.

Table 3 Validation of the model using landslide density index (LDI)

\begin{tabular}{|c|c|c|c|c|c|c|c|c|}
\hline Landslide Susceptibility Class (with LSI) & NPLSM & $\%$ PLSM (c) & NTLSP & \%TLSP (a) & $\mathrm{LDI}=\mathrm{a} / \mathrm{c}$ & NVLSP & $\%$ VLSP (b) & $\mathrm{LDI}=\mathrm{b} / \mathrm{c}$ \\
\hline Very Low (- $11.308--6.106)$ & 33,611 & 15.16 & 75 & 0.56 & 0.04 & 6 & 0.18 & 0.01 \\
\hline $\operatorname{Low}(-6.106--3.580)$ & 55,665 & 25.10 & 259 & 1.93 & 0.08 & 52 & 1.54 & 0.06 \\
\hline Moderate $(-3.580--1.117)$ & 55,230 & 24.91 & 1673 & 12.48 & 0.50 & 436 & 12.94 & 0.52 \\
\hline High $(-1.117-1.600)$ & 49,709 & 22.42 & 4929 & 36.77 & 1.64 & 1173 & 34.82 & 1.55 \\
\hline Very High (1.600-7.520) & 27,532 & 12.42 & 6468 & 48.25 & 3.89 & 1702 & 50.52 & 4.07 \\
\hline
\end{tabular}

Note: $L S I$ Landslide Susceptibility Index, NPLSM Number of pixels in a landslide susceptibility map, \%PLSM Percent of pixels in a landslide susceptibility map, NTLSP Number of training landslide pixels, \%TLSP Percent of training landslide pixels, NVLSP Number of landslide pixels, \%VLSP Percent of landslide validation pixels, and LDI Landslide density index 


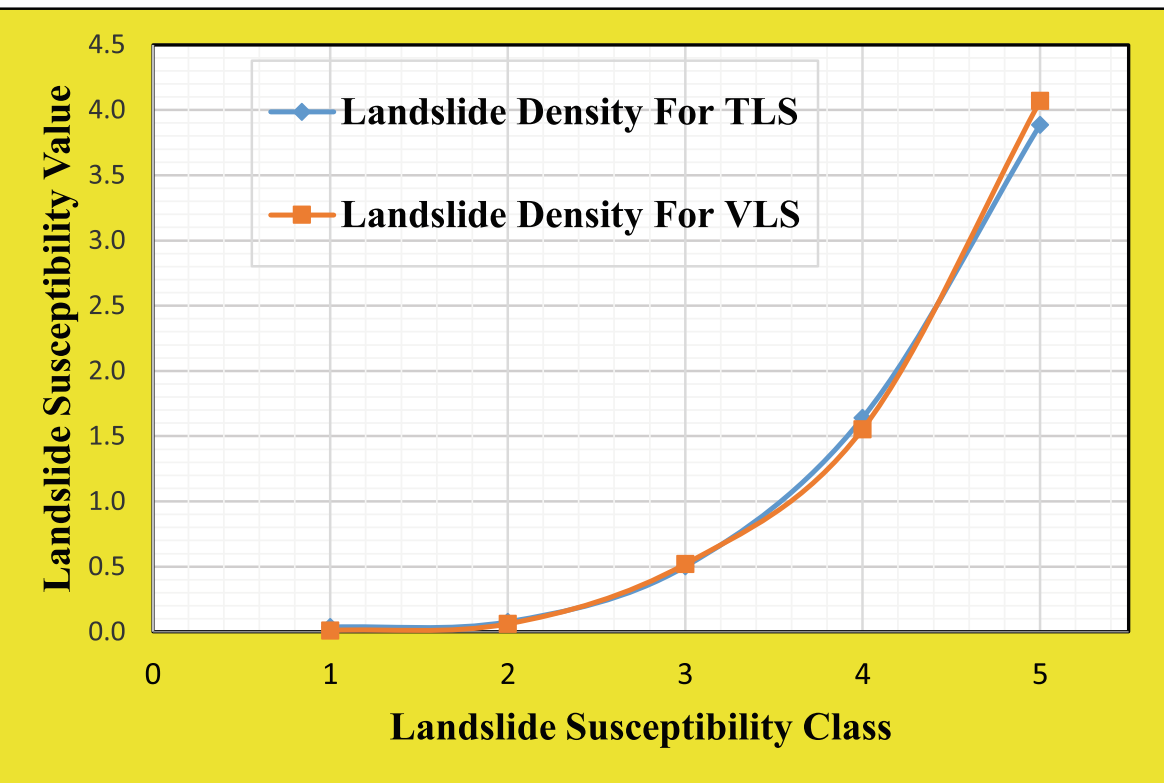

Fig. 10 The relation between landslide susceptibility class and landslide density (Note: TLS = Training landslide; VLS = Validating landslide)

Providing adequate drainage is important to prevent the occurrence of new landslides and reactivation of existing landslides. This includes controlling gully erosion and reduction of stream/river erosion through gabion protection. During the fieldwork, it was observed that most of the springs emanated on the failed slope section and local people used this water for irrigation purposes on this failed slope section. The local government must prohibit this section and divert the water to a stable area for irrigation. To reduce the effect of a landslide on human lives and engineering structures, the high and very high susceptibility classes should be provided with the necessary mitigation measures. Areas of new cracks which indicate the future landslide occurrences can be avoided by restricting or prohibiting settlement in such areas. In addition, relocating people who are living in these hazardous zones and minimizing any development activities can help to reduce the impact of landslides in the study area in particular and the Blue Nile (Abay) Basin in general. Moreover, detail geotechnical and geophysical investigations are also important to make a thorough investigation for designing sophisticated landslide mitigation measures.

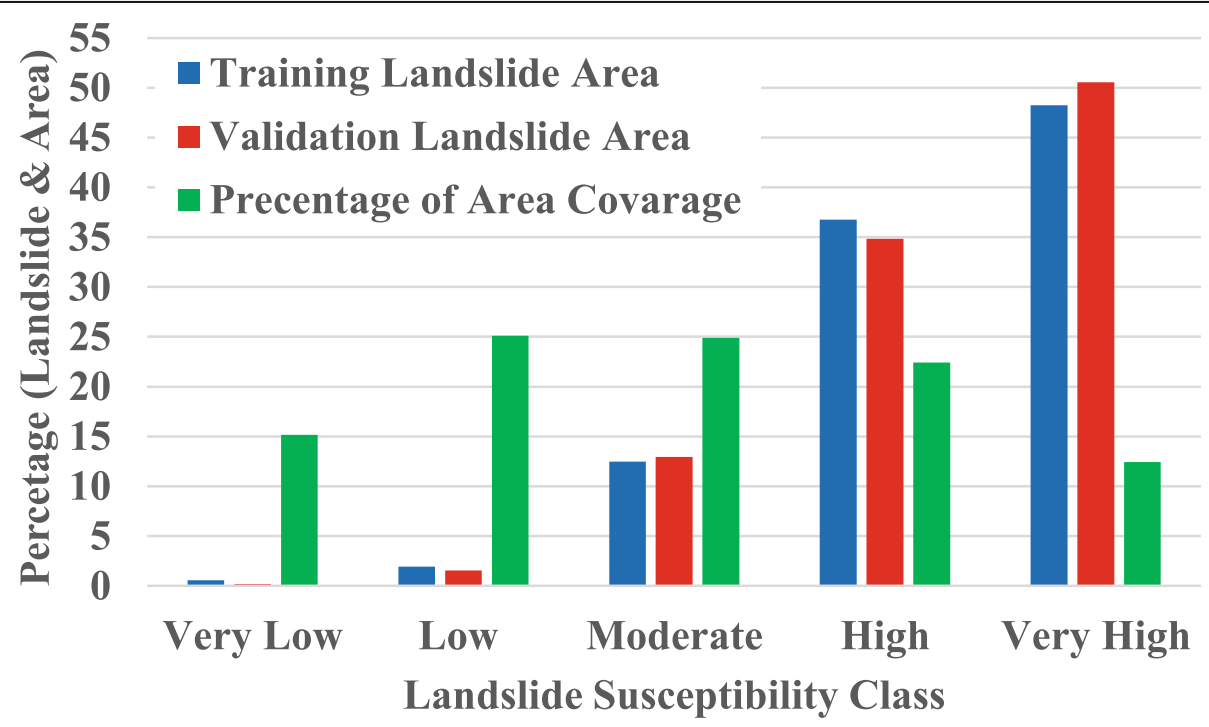

Fig. 11 Bar graph showing validation of the model using landslide density index 


\section{Acknowledgments}

The first author would like to express his heartfelt acknowledgment to Mr. Azemeraw Wubalem and Mr. Tilahun Mersha for their constructive comments. He also would like to thank Assosa University for sponsoring his MSc study at Addis Ababa Science and Technology University. Finally, we would like also to acknowledge Addis Ababa Science and Technology University, particularly the Department of Geology and Department Civil Engineering for their support and material provision during the data collection phase.

\section{Authors' contributions}

NG as a first author participated in different phases of the research work starting from literature review, secondary data collection in different offices and primary data collection in the field, landslide inventory mapping and landslide susceptibility map preparation. MM as an advisor also participated in this research by giving critical comments for improvement in each phase of the research and supervised the first author by checking the validity of the data and results and further enriched the research by adding his inputs. This helped to improve the quality of the research significantly. Finally, both authors approved the manuscript submission.

\section{Funding}

Addis Ababa Science and Technology University and Assosa University are acknowledged for the partial funding of this research work as a fulfillment to the requirement of the master's degree for the first author.

\section{Availability of data and materials}

The available data sources were described in the main body of manuscript.

\section{Competing interests}

The authors confirm that they have no competing interests with any individual or organization.

\section{Author details}

'Department of Geology, College of Applied Sciences, Addis Ababa Science and Technology University, P.O. Box: 16417, Addis Ababa, Ethiopia.

${ }^{2}$ Department of Geology, College of Natural and Computational Science, Assosa University, P.O. Box 18, Assosa, Ethiopia. ${ }^{3}$ Mineral Exploration, Extraction and Processing Center of Excellence, Addis Ababa Science and Technology University, Addis Ababa, Ethiopia.

Received: 18 July 2020 Accepted: 8 February 2021

Published online: 27 February 2021

\section{References}

Abebe B, Dramis F, Fubelli G, Umar M, Asrat A (2010) Landslides in the Ethiopian highlands and the rift margins. Afr Earth Sci 56(4-5):131-138. https://doi. org/10.1016/j.jafrearsci.2009.06.006

Agterberg F, Bonham-Carter G, Cheng Q (1993) Weights of evidence modeling and weighted logistic regression for mineral potential mapping. University Press, Oxford

Aleotti P, Chowdhury R (1999) Landslide hazard assessment: summary review and new perspectives. Bull Eng Geol Environ 58(1):21-44. https://doi.org/10.1007/ s100640050066

Anbalagan R (1992) Landslide hazard evaluation and zonation mapping in mountainous terrain. Eng Geol 32(4):269-277. https://doi.org/10.1016/00137952(92)90053-2

Anis Z, Wissem G, Vali V, Smida H, Essghaier GM (2019) GIS-based landslide susceptibility mapping using bivariate statistical methods in north-western. 708-726

Ayalew $L$ (1999) The effect of seasonal rainfall on landslides in the highlands of Ethiopia. Bull Eng Geol Environ 58(1):9-19. https://doi.org/10.1007/s10064 0050065

Ayalew L (2000) Factors affecting slope stability in the Blue Nile basin. In: Bromhead M, Dixon N, Ibsen M (eds) Landslides: in research, theory and practice. Thomas Telford, Cardiff, Wales

Ayalew L, Yamagishi H (2004) Slope movements in the Blue Nile basin, as seen from landscape evolution perspective. Geomorphology 57:97-116

Ayalew L, Yamagishi H (2005) The application of GIS-based logistic regression for landslide susceptibility mapping in the Kakuda-Yahiko Mountains, Central Japan. Geomorphology 65(1-2):15-31. https://doi.org/10.1016/j.geomorph.2 004.06.010
Ayenew T, Barbieri G (2005) Inventory of landslides and susceptibility mapping in the Dessie area, northern Ethiopia. 77:1-15. https://doi.org/10.1016/j. enggeo.2004.07.002

Blahut J, VanWesten C, Sterlacchini S (2010) Analysis of landslide inventories for accurate prediction of debris-flow source areas. Geophys J R Astron Soc 119:36-51

Bonham-Carter G (1994) Geographic information systems for geoscientists: modeling with GIS. Oxford: Pergamon Press 32(11):302-334

Bonham-Carter G, Agterberg F, Wright D (1988) Integration of geological datasets for gold exploration in Nova Scotia. Dig Geol GIS:15-23

Bonham-Carter G, Agterberg F, Wright D (1989) Weights of evidence modelling: a new approach to mapping mineral potential. Stat Appl in Earth Sci 89-9: 171-183

Bousta M, Ait BL (2018) Weights of evidence method for landslide susceptibility mapping in Tangier, Morocco MATEC Web of Conferences, vol 149. https:// doi.org/10.1051/matecconf/201814902042

Brabb E (1993) Proposal for worldwide landslide hazard maps, proceedings of 7th international conference and field workshop on landslide in Czech and Slovak republics 15-27

Carrara A, Crosta G, Frattini P (2003) Geomorphological and historical data in assessing landslide hazard. Earth Surf Process Landf 28:1125-1142

Chen W (2014) Application of weights-of-evidence model in landslide susceptibility mapping at Baozhong region in Baoji, China, pp 791-810

Conforti M, Pascale S, Robustelli G, Sdao F (2014) Evaluation of prediction capability of the artificial neural networks for mapping landslide susceptibility in the Turbolo River catchment (northern Calabria, Italy). Catena 113:236-250. https://doi.org/10.1016/j.catena.2013.08.006

Crozier M (1986) Landslides: causes, consequences and environment, Croom helm, London. Géog Phys Quatern 41(3):409

Cruden DM (1991) A simple definition of a landslide. In: Bulletin of the International Association of Engineering Geology, vol 43, pp 27-29. https:// doi.org/10.1007/BF02590167

Dai F, Lee FC (2002) Landslide characteristics and slope instability modelling using GIS, Lantau Island, Hong Kong. Geomorphology 42:213-238

Dai FC, Lee CF, Ngai YY (2002) Landslide risk assessment and management: an overview. Eng Geol 64:65-87. https://doi.org/10.1016/50013-7952(01)00093-X

De Vallejo LIG, Ferrer M (2011) Geological engineering. CRC Press/Balkema, Leiden

Ermias B, Raghuvanshi T, Abebe B (2017) Landslide Hazard zonation (LHZ) around Alemketema town, north Showa zone, Central Ethiopia - a GIS based expert evaluation approach. Int J Earth Sci Eng 10(01):33-44. https://doi.org/10.212 76/ijee.2017.10.0106

Gadtaula A, Dhakal S (2019) Landslide susceptibility mapping using weight of evidence method in Haku, landslide susceptibility mapping using weight of evidence method in Haku, Rasuwa District, Nepal, vol 0-10. https://doi.org/1 0.3126/jngs.v58i0.24601

Ghosh JK, Devanjan B, Swej KS (2012) Fuzzy knowledge-based GIS for zonation of landslide. Sci Eng 2:2-13

Ghosh P, Huang L, Yu B, Tiwari RC (2009) Semiparametric Bayesian approaches to joinpoint regression for population-based cancer survival data. Comput Stat Data Anal 53:4073-4082

Girma F, Raghuvanshi TK, Ayenew T, Haile Mariam T (2015) Landslide hazard zonation in Ada Berga district, Central Ethiopia - a GIS-based statistical approach. J Geom 90:25-38

Guzzetti F (2000) Landslide fatalities and evaluation of landslide risk in Italy. Eng Geol 58:89-107

Guzzetti F, Carrara A, Cardinali M, Reichenbach P (1999) Landslide hazard evaluation: a review of current techniques and their application in a multiscale study, Central Italy. Geomorphology 31(1-4):181-216

Hansen A (1984) Landslide Hazard Analysis. In: Brunsen D, Prior DB (eds) Slope instability. Wiley, New York, pp 523-602

Huang J, Zhou Q, Wang F (2015) Annals of GIS mapping the landslide susceptibility in Lantau Island, Hong Kong, by frequency ratio and logistic regression model. Ann GIS 21(3):191-208. https://doi.org/10.1080/19475683.2014.992373

Ibrahim W (2011) Road sector development and economic growth in Ethiopia. Ethiop J Econ:101-146

Janevski B, Milanovski M (2018) Comparison between limit equilibrium approach and finite element method for slope stability analysis in anisotropic rocks with low quality. Ce/papers 2(2-3):651-656

Kanungo D, Arora M, Sarkar S, Gupta R (2006) A comparative study of conventional, ANN black box, fuzzy and combined neural and fuzzy weighting procedures for landslide susceptibility zonation in Darjeeling Himalayas. Eng Geol 85(3-4):347-366 
Kanungo D, Arrora M, Sarkar S, Gupta R (2009) Landslide susceptibility zonation (LSZ) mapping-a review. J South Asia Disaster Stud 2:81-105

Korme T, Acocella V, Abebe B (2004) The role of pre-existing structures in the origin, propagation and architecture of faults in the Main Ethiopian rift. Gondwana Res 7:467-479

Kumar R, Anbalagan R (2019) Landslide susceptibility mapping of the Tehri reservoir. J Earth Syst Sci. https://doi.org/10.1007/s12040-019-1159-9

Kumar R, Shuichi DE, Nonomura A, Yamanaka EM (2008) GIS-based weights-ofevidence modelling of rainfall-induced landslides in small catchments for landslide susceptibility mapping, pp 311-324. https://doi.org/10.1007/s00254-007-0818-3

Lee S, Choi J, Min K (2004) Probabilistic landslide hazard mapping using GIS and remote sensing data at Boun, Korea. J Remote Sens 25(11):2037-2052

Lee S, Min K (2001) Statistical analysis of landslide susceptibility at Yongin, Korea. Environ Geol 40:1095-1113. https://doi.org/10.1007/s002540100310

Lee S, Sambath T (2006) Landslide susceptibility mapping in the Damrei Romel area, Cambodia using frequency ratio and logistic regression models. Environ Geol 50(6):847-855. https://doi.org/10.1007/s00254-006-0256-7

Lee S, Talib J (2005) Probabilistic landslide susceptibility and factor effect analysis. Environ Geol 47(7):982-990

Leroi E (1996) Landslide hazard - risk maps at different scales: objectives, tools and developments. In: Senneset K (ed) Landslides Glissements de terrain, 1st edn. Rotterdam, Balkenma, pp 35-51

Mahdadi F, Boumezbeur A, Hadji R, Kanungo DP, Zahri F (2018) GIS-based landslide susceptibility assessment using statistical models: a case study from Souk Ahras province, N-E Algeria

Mathew J, Jha VK, Rawat GS (2007) Landslide susceptibility zonation mapping and its validation in part of Garhwal lesser Himalaya, India, using binary logistic regression analysis and receiver operating characteristic curve method (March 2008), 17-26. doi: https://doi.org/10.1007/s10346-008-0138-z

Mersha T, Meten M (2020) GIS-based landslide susceptibility mapping and assessment using bivariate statistical methods in Simada area, northwestern. https://doi.org/10.1186/s40677-020-00155-x

Meten M, Bhandary NP, Yatabe R (2015a) Effect of landslide factor combinations on the prediction accuracy of landslide susceptibility maps in the Blue Nile Gorge of Central Ethiopia. Geoenvironmental Disasters 2:9. https://doi.org/1 0.1186/s40677-015-0016-7

Meten M, Bhandary NP, Yatabe R (2015b) GIS- based Frequency ratio and logistic regression Modelling for landslide susceptibility mapping of Debre Sina area in Central Ethiopia. J Mt Sci 12(6):1355-1372

Mohr P (1986) Sequential aspects of the tectonic evolution of Ethiopia. Mem Soc Geol Ital 31:447-461

Neuhäuser B, Bodo D, Birgit T (2012) GIS-based assessment of landslide susceptibility on the base of the weights-of-evidence model. Landslides 9: 511-528. https://doi.org/10.1007/s10346-011-0305-5

Pan X, Nakamura H, Nozaki T, Huang X (2008) A GIS-based landslide hazard assessment by multivariate analysis landslides. J Jpn Landslide Soc 45(3):187-195

Pardeshi SD, Autade SE, Pardeshi SS (2013) Landslide hazard assessment: recent trends and techniques. SpringerPlus 2:523. http://www.springerplus.com/ content/2/1/523

Piacentini D, Troini F, Soldati M, Notamicola C, Saveli D, Scheneiderbauer S, Strada C (2012) Statistical analysis for assessing shallow-landslide susceptibility in South Tyrol (South-Eastern Alps, Italy). Geophys J R Astron Soc 151-152:196-206

Pradhan B, Lee S (2010) Landslide susceptibility assessment and factor effect analysis: back-propagation artificial neural networks and their comparison with frequency ratio and bivariate logistic regression modeling. Environ Model Softw 25:747-759

Pradhan B, Oh H-J, Buchroithner M (2010) Weights-of-evidence model applied to landslide susceptibility mapping in a tropical hilly area. Geomatics Nat Hazards Risk 1:199-223

Raghuvanshi T, Negassa L, Kala P (2015) GIS based grid overlay method versus modeling approach - a comparative study for landslide hazard zonation (LHZ) in Meta Robi District of west Showa zone in Ethiopia. Egypt J Remote Sens Space Sci 18(2):235-250. https://doi.org/10.1016/j.ejrs.2015.08.001

Raghuvanshi TK, Ibrahim J, Ayalew D (2014) Slope stability susceptibility evaluation parameter (SSEP) rating scheme - an approach for landslide hazard zonation. J Afr Earth Sci 99:595-612

Schicker R, Moon V (2012) Comparison of bivariate and multivariate statistical approaches in landslide susceptibility mapping at a regional scale. Geomorphology 161-162:40-57
Siddle HJ, Jones DB, Payne HR (1991) Development of a methodology for landslip potential mapping in the Rhondda Valley. In: Chandler RJ (ed) Slope stability engineering. Thomas Telford, London, pp 137-142

Sumatra W, Muslim D, Sulaksana N, Dasatriana Y (2015) Weights of Evidence Method for Landslide Susceptibility Mapping in Tandikek and Damar 4(10): $1283-1290$

Suzen M, Doyuran V (2004) A comparison of the GIS based landslide susceptibility assessment methods: multivariate versus bivariate. Environ Geol 45(5):665-679

Suzen M, Doyuran V (2004a) Data driven bivariate landslide susceptibility assessment using geographical information systems: a method and application to Asarsuyu catchment, Turkey. Eng Geol 71:303-321

Temesgen B, Mohammed U, Asfawosen A (1999) Landslide hazard on the Dabicho, Wondo genet area: the case of June 18, 1996 event. SENET: Ethiop J Sci 22(I):127-I140

Van Westen CJ, Rengers N, Soeters R (2003) Use of geomorphological information in indirect landslide susceptibility assessment. Nat Hazards 30:399-419

Van Westen CJ, Rengers N, Terlien M (1997) Prediction of the occurrence of slope instability phenomena through GIS-based hazard zonation. Geol Rundsch 86: 4004-4414

Van Westen CJ, Terlien TJ (1996) An approach towards deterministic landslide hazard analysis in GIS. A case study from Manizales (Colombia). Earth Surf Proc Landforms 21:853-868

Woldearegay K (2008) Characteristics of a large-scale landslide triggered by heavy rainfall in Tarmaber area, central highlands of Ethiopia. Geophys Res Abstr 10: EGU2008-A-04506 2008, SRef - ID:16077962/gra/EGU2008-A-04506

Woldearegay K (2013) Review of the occurrences and influencing factors of landslides in the highlands of Ethiopia: with implications for infrastructural development. Momona Ethiop J Sci 5(1):3-31. https://doi.org/10.4314/mejs.v5i1.85329

Wubalem A (2021) Landslide susceptibility mapping using statistical methods in Uatzau catchment area, northwestern Ethiopia. https://doi.org/10.1186/s4 0677-020-00170-y

Wubalem A, Meten M (2020) Landslide susceptibility mapping using information value and logistic regression models in Goncha Siso Eneses area, northwestern Ethiopia. SN Applied Sci. https://doi.org/10.1007/s42452-020-2563-0

Yalcin A (2008) GIS-based landslide susceptibility mapping using analytical hierarchy process and bivariate statistics in Ardesen (Turkey): comparisons of results and confirmations. CATENA 72(1):1-12

Yilmaz I (2009) Landslide susceptibility mapping using frequency ratio, logistic regression, artificial neural networks and their comparison: a case study from Kat landslides (Tokat-Turkey). J Comput Geosci 35:1125-1138

\section{Publisher's Note}

Springer Nature remains neutral with regard to jurisdictional claims in published maps and institutional affiliations.

\section{Submit your manuscript to a SpringerOpen ${ }^{\circ}$ journal and benefit from:}

- Convenient online submission

- Rigorous peer review

- Open access: articles freely available online

- High visibility within the field

- Retaining the copyright to your article

Submit your next manuscript at $\boldsymbol{\nabla}$ springeropen.com 